\title{
Field measurements of trace gases emitted by prescribed fires in southeastern US pine forests using an open-path FTIR system
}

\author{
S. K. Akagi ${ }^{1}$, I. R. Burling ${ }^{1}$, A. Mendoza ${ }^{2}$, T. J. Johnson ${ }^{2}$, M. Cameron ${ }^{3}$, D. W. T. Griffith ${ }^{3}$, C. Paton-Walsh ${ }^{3}$, \\ D. R. Weise ${ }^{4}$, J. Reardon ${ }^{5}$, and R. J. Yokelson ${ }^{1}$ \\ ${ }^{1}$ University of Montana, Department of Chemistry, Missoula, MT 59812, USA \\ ${ }^{2}$ Pacific Northwest National Laboratories, Richland, WA 99354, USA \\ ${ }^{3}$ University of Wollongong, Department of Chemistry, Wollongong, New South Wales, Australia \\ ${ }^{4}$ USDA Forest Service, Pacific Southwest Research Station, Forest Fire Laboratory, Riverside, CA 92507, USA \\ ${ }^{5}$ USDA Forest Service, Rocky Mountain Research Station, Fire Sciences Laboratory, Missoula, MT 59808, USA
}

Correspondence to: R. J. Yokelson (bob.yokelson@umontana.edu)

Received: 24 March 2013 - Published in Atmos. Chem. Phys. Discuss.: 10 July 2013

Revised: 22 October 2013 - Accepted: 23 October 2013 - Published: 8 January 2014

\begin{abstract}
We report trace-gas emission factors from three pine-understory prescribed fires in South Carolina, US measured during the fall of 2011. The fires were more intense than many prescribed burns because the fuels included mature pine stands not subjected to prescribed fire in decades that were lit following an extended drought. Emission factors were measured with a fixed open-path Fourier transform infrared (OP-FTIR) system that was deployed on the fire control lines. We compare these emission factors to those measured with a roving, point sampling, land-based FTIR and an airborne FTIR deployed on the same fires. We also compare to emission factors measured by a similar OP-FTIR system deployed on savanna fires in Africa. The data suggest that the method used to sample smoke can strongly influence the relative abundance of the emissions that are observed. The majority of fire emissions were lofted in the convection column and were sampled by the airborne FTIR. The roving, ground-based, point sampling FTIR measured the contribution of individual residual smoldering combustion fuel elements scattered throughout the burn site. The OP-FTIR provided a $\sim 30 \mathrm{~m}$ path-integrated sample of emissions transported to the fixed path via complex ground-level circulation. The OP-FTIR typically probed two distinct combustion regimes, "flaming-like" (immediately after adjacent ignition and before the adjacent plume achieved significant vertical development) and "smoldering-like." These two regimes are denoted "early" and "late", respectively. The path-integrated sample of the ground-level smoke layer adjacent to the fire
\end{abstract}

from the OP-FTIR provided our best estimate of fire-line exposure to smoke for wildland fire personnel. We provide a table of estimated fire-line exposures for numerous known air toxics based on synthesizing results from several studies. Our data suggest that peak exposures are more likely to challenge permissible exposure limits for wildland fire personnel than shift-average $(8 \mathrm{~h})$ exposures.

\section{Introduction}

Biomass burning is a significant, global source of trace gases and particles that impact the chemical composition and radiative balance of the atmosphere (Crutzen and Andreae, 1990). Biomass burning includes open fires in forests, savannas, crop residues, and peatlands as well as biofuel and garbage burning (Akagi et al., 2011). In the US, wild and prescribed fires in forests account for a significant fraction of the total fire activity (Hardy et al., 2001; Melvin, 2012). In the southeastern US, prescribed fires are ignited in some wildlands to help reduce the risk of wildfire and smoke impacts by consuming accumulated fuels under weather conditions that allow smoke production and dispersion to be at least partially controlled (Hardy et al., 2001; Wiedinmyer and Hurteau, 2010; Cochrane et al., 2012) and to promote the natural, beneficial role that fire plays in fire-adapted ecosystems (Biswell, 1989; Carter and Foster, 2004; Keeley et al., 2009). The ideal "smoke management" scenario 
occurs when the majority of the smoke is produced by flaming combustion, lofted via convection, and directed away from major population centers. This requires that fuel conditions, boundary layer depth, wind speed, and wind direction are within specific limits. Land managers try to minimize prolonged smoldering outside the envelope of convection from the flame front. This type of combustion is often termed "residual smoldering combustion", or RSC, and typically produces un-lofted smoke that accounts for many of the local-scale air quality impacts of prescribed burning (Bertschi et al., 2003; Achtemeier, 2006). There are very few peer-reviewed field measurements of the emissions from RSC (Bertschi et al., 2003; Burling et al., 2011; Akagi et al., 2013) and these measurements are becoming more desirable with increased recognition that RSC is a major fuel consumption process in some ecosystems (Christian et al., 2007; Greene et al., 2007; Hyde et al., 2011; Turetsky et al., 2011; Benscoter et al., 2011).

This work is part of a series of studies focusing on smoke emissions from prescribed fires on US Department of Defense (DoD) bases. Previous studies from this series include Burling et al. (2010) who sampled the emissions from fuels collected on bases that were burned in a large laboratory combustion facility; Burling et al. (2011) and Akagi et al. $(2012,2013)$ who described airborne and ground-based smoke measurements on bases in the western and southeastern US; and Yokelson et al. (2013) who synthesized the laboratory and field results. In the previous studies, Burling et al. (2011) and Akagi et al. (2013) used a mobile, closed-cell FTIR system to search for and sample RSC point sources based on the observation of visible smoke plumes emanating from specific smoldering logs, stumps, litter, etc. In this study we focus on "passive" ground level emissions measurements using a static, open-path Fourier transform infrared (OP-FTIR) gas analyzer system that measured all smoke (including both flaming and smoldering emissions) that drifted through the fixed measurement path of $\sim 30 \mathrm{~m}$. Griffith et al. (1991) was first to employ an OP-FTIR system to study biomass burning emissions. More recently, OP-FTIR has been used to study polluted air in challenging environmental or industrial conditions, such as measuring volcanic emissions or aircraft exhaust (Gosz et al., 1988; Oppenheimer and Kyle, 2007; Schäfer et al., 2005). Recently, Wooster et al. (2011) revived the use of OP-FTIR for field measurements of biomass burning, reporting emission ratios (ER) and emission factors (EF) for $\mathrm{CO}_{2}, \mathrm{CO}, \mathrm{CH}_{4}, \mathrm{HCHO}$, and $\mathrm{NH}_{3}$ from savanna fires in Kruger National Park, South Africa.

An important application of our open-path data is better understanding of the composition of ground-level smoke from prescribed burning to help minimize human exposure to potentially harmful toxins. Smoke could affect human health via numerous, complex, and poorly understood mechanisms. In particular, firefighters, burn managers, and other wildland fire personnel are subjected to a complex mixture of combustion-generated gases and respirable particles. This in- cludes at least five chemical groups classified as known human carcinogens by the International Agency for Research on Cancer (IARC), other species classified by the IARC as probable or possible human carcinogens, and at least 26 chemicals listed by the US EPA as hazardous air pollutants (Naeher et al., 2007). Adverse health effects caused by smoke emitted during a fire could potentially include upper respiratory symptoms (Swiston, 2008), neurological symptoms, and cancer (though previous studies have not found a strong link between the two, Demers et al., 1994). Only a few studies in the literature have evaluated occupational exposure to smoke among firefighters (Materna et al., 1992; Reinhardt and Ottmar, 1997, 2004; Adetona et al., 2011).

Measuring fire-line exposures to various toxins present in smoke for comparison to established exposure limits is not simple because fire intensity, fuel composition, and weather conditions are constantly changing and thereby modifying the smoke chemistry and dilution occurring in the work environment (Sharkey, 1997). Different fire types also pose different conditions; several studies found that exposures to pollutants were higher among firefighters at prescribed fires than at wildfires (Reinhardt and Ottmar, 2004; Sharkey, 1997). In addition, smoke exposure can vary by work activity (e.g. direct attack, lighting, mop-up) (Reinhardt and Ottmar, 2004). For the typical morning prescribed burn, increasing afternoon winds may increase smoke distribution and risk of smoke overexposure for some workers. Various measurement techniques, including electronic dosimeters, liquid chromatography, and gas chromatography/flame ionization detection (FID) have been employed to measure different species in smoke. This work is the first to assess fire-line exposure using the open-path FTIR technique.

In summary, this study first describes the OP-FTIR system employed on three Fort Jackson fires and the data reduction approach. We then present a time series of OP-FTIR results with the simultaneous observations of the other FTIR instruments noted for perspective. We calculate OP-FTIR EF for the trace gases detected and these $\mathrm{EF}$ are then compared to EF from the other FTIRs on the same fires and to EF measured by an OP-FTIR system deployed on savanna fires. Finally, we combine the OP-FTIR mixing ratio measurements on the fire-line with results from the other DoD studies to generate a preliminary assessment of fire-line exposure to air toxins.

\section{Experimental details}

\subsection{Open-path FTIR measurements}

Measurements of ground-level smoke on the perimeter of three prescribed fires at Fort Jackson near Columbia, South Carolina (SC), US were made using a Bruker OPAG-22 OPFTIR (Fig. 1a). The OPAG-22 is a tripod-mounted, fieldportable FTIR system that can be used to monitor trace gas 
species in the atmosphere across distances of tens to hundreds of meters. An active configuration was used with an unmodulated $\mathrm{SiC}$ glowbar source and sender telescope at one end of the light path and the FTIR with receiver telescope at the other. The source was powered $(\sim 20 \mathrm{~W})$ using a $12.6 \mathrm{~V}$ DC automobile battery. The $1200^{\circ} \mathrm{C} \mathrm{SiC} \mathrm{source}$ was mounted at the focal point of an F/4 Newtonian telescope with a $150 \mathrm{~mm}$ clear aperture. The sender telescope directed a collimated, broadband IR beam to a $137 \mathrm{~mm}$ receiver telescope coupled to the OPAG-22 FTIR spectrometer. Pathlengths of $29.3-32.2 \mathrm{~m}$ were used to optimize infrared intensity and sensitivity (Fig. 1b). On the receiving end, the OPAG-22 was powered by two automobile batteries in series to provide $\sim 25 \mathrm{VDC}$. The nominal field of view of the spectrometer is 30 milliradians (mrad), which was reduced to $10 \mathrm{mrad}$ by the F/3 receiver telescope (Fig. 1a). The interferometer uses dual retro-reflecting cube corner mirrors in an inverted pendulum mechanism that does not need alignment in the field. The FTIR used a Stirling-cycle cooled mercury cadmium telluride (MCT) detector with a proprietary software correction for nonlinearity (Keens, 1990). Spectra were recorded at a resolution of $1.5 \mathrm{~cm}^{-1}$ and 50 scans were co-added to give increased signal-to-noise ratio (SNR) at a time resolution of $134 \mathrm{~s}$ per spectrum. After aligning the telescopes, an ambient emission spectrum was recorded with the source turned off. This spectrum accounts for emission from the ambient-temperature environment which is modulated by the interferometer and detected in the FTIR spectra. The ambient emission spectrum was subtracted from all measured globar spectra before further analysis.

The emission-corrected sample spectra were then analyzed either directly as single-beam spectra, or as transmission spectra ratioed to a background air spectrum taken before the fire. Ratioing to background was used only in spectral regions where the continuum spectrum of the sourcetelescope-interferometer system was complex and could not be fitted well by the analysis procedure. The background spectrum was also used to characterize the composition of the pre-fire atmosphere. Analysis was by iterative non-linear least-squares fitting of the measured spectra by calculated spectra as described in previous work (Burling et al., 2011; Griffith et al., 2012). The calculated spectra are based on HITRAN (Rothman et al., 2009) and Pacific Northwest National Laboratory (Sharpe et al., 2004; Johnson et al., 2006, 2010) spectral databases, and include the effects of environmental pressure and temperature as well as the instrument line shape and resolution. Spectra were analyzed in domains of typically 10 to $200 \mathrm{~cm}^{-1}$ width, with each region targeting one or more trace gases (see Table A1 in Appendix A for all species reported and the spectral analysis regions from which they were retrieved). Typical precision of measurements is $<1 \%$ for dominant species such as $\mathrm{CO}_{2}$, $\mathrm{CO}$ and $\mathrm{CH}_{4}$, but accuracy may be a few percent, varying from species to species; Smith et al. (2011) provide a detailed analysis of the accuracy of OP-FTIR measurements.
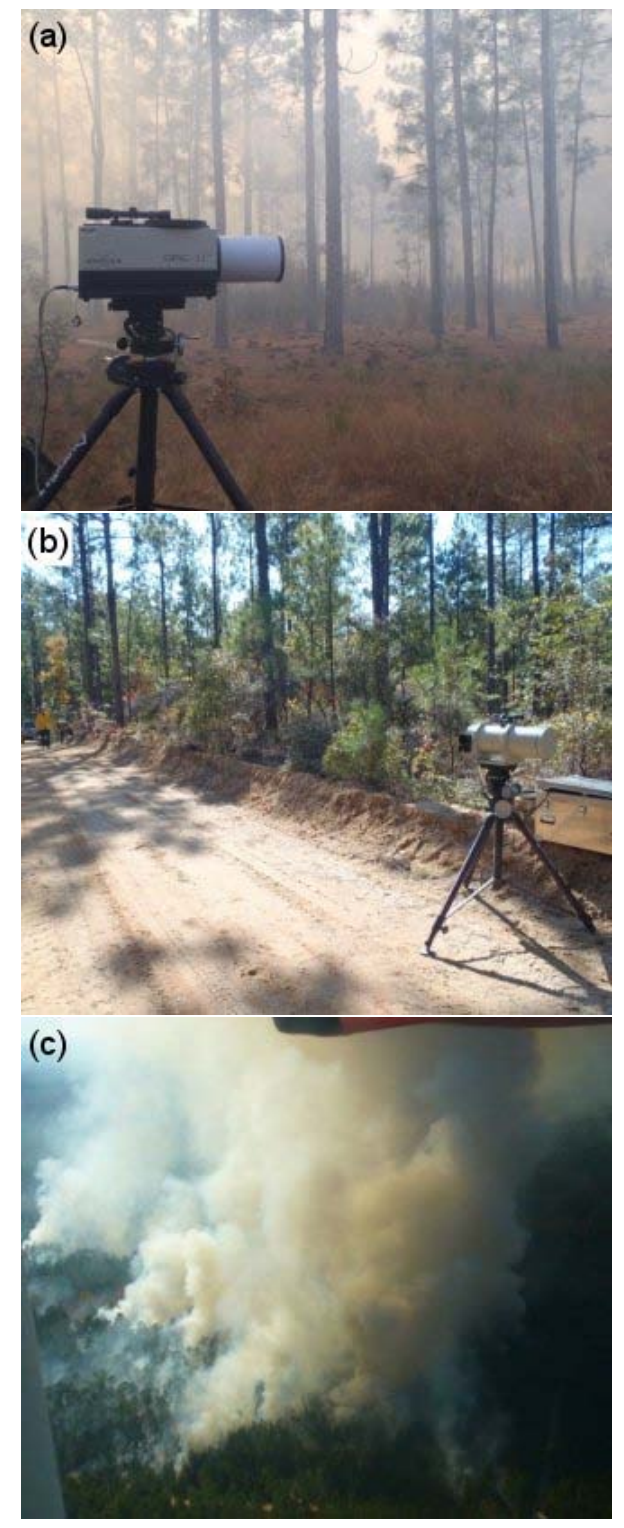

Fig. 1. (a) Photograph of the OPAG-22 spectrometer system with receiver telescope in the field during the 2 November fire. (b) Photograph of the sender and receiver telescopes separated by an optical path of $\sim 30 \mathrm{~m}$ taken in clean air before ignition on 30 October. (c) Photograph of the 2 November fire from the airborne platform used by the airborne FTIR system. Pictures of fuels sampled by the LAFTIR can be found in Akagi et al. (2013).

Detection limits for trace species are typically 1-10 ppb. Excess mixing ratios (EMRs) for any species $X$ detected when smoke filled the optical path (denoted $\Delta \mathrm{X}$, the mixing ratio of species $\mathrm{X}$ in a smoke plume layer minus its mixing ratio in background air) were obtained directly from the transmission spectra or by difference between the appropriate single beam retrievals for $\mathrm{H}_{2} \mathrm{O}, \mathrm{CO}_{2}, \mathrm{CO}$, and $\mathrm{CH}_{4}$ in the plume and prefire. All the retrieved excess mixing ratios are listed in the Supplement by individual species for each fire (Table S1). 


\subsection{Other gas-phase sampling instruments}

In addition to measurements made by the OP-FTIR, two closed-cell FTIR systems were employed: (1) an Airborne FTIR (AFTIR) to sample lofted fresh and photochemically aged smoke (Fig. 1c), and (2) a mobile, LAnd-based FTIR (LAFTIR) system to sample point sources of smoldering smoke (Akagi et al., 2013). This work will focus primarily on gas-phase species measured by the OPAG-22 (hereafter referred to as the OP-FTIR) system, but it is instructive to compare with the other FTIRs at times. Whole air sampling (WAS) canisters were also used on the ground and in the air to measure an extensive suite of gases (mostly non-methane organic compounds, NMOCs) and are reported in Akagi et al. (2013).

\subsection{Calculation of emission ratios (ERs) and emission factors (EFs)}

Excess mixing ratios for FTIR species were calculated following the procedure in Sect. 2.1. The molar emission ratio (ER) is calculated by dividing $\Delta \mathrm{X}$ by the EMR of a reference species $\Delta \mathrm{Y}$, usually $\Delta \mathrm{CO}$ or $\Delta \mathrm{CO}_{2}$, measured in the same fresh smoke sample as " $X$ ". Since all species are retrieved from the same spectrum at the same time, emission ratios can be determined for any pair of species at each spectrum time-step (for the OP-FTIR $\sim 134$ s). In this study, we first combined all the OP-FTIR measurements from each fire to compute a single fire-averaged initial emission ratio (and $1-\sigma$ standard deviation) for each fire. We computed the fireaveraged ERs from the slope of the linear least-squares regression line with the intercept forced to zero when plotting $\Delta \mathrm{X}$ against $\Delta \mathrm{Y}$ (Yokelson et al., 1999). The intercept is forced to zero because the background concentration is typically well known and variability in the plume can affect the slope and intercept if the intercept is not forced. This method heavily weights the large excess mixing ratios that may reflect higher rates of fuel consumption and data that have higher SNR. For $\mathrm{NH}_{3}$ and $\mathrm{CH}_{3} \mathrm{COOH}$, for unknown reasons, there was a large positive intercept in the plots versus $\mathrm{CO}$ and the intercept was not forced, but the slope was still well-constrained and provides our best ER estimate. For comparison we also summed the excess amounts of $X$ and $\mathrm{Y}$ over time and took the ratio $\Sigma \Delta \mathrm{X} / \Sigma \Delta \mathrm{Y}$ as an alternate estimate of the ER. The ERs calculated by this summation method were within $20 \%$ of those calculated using the regression method. For example, the $\mathrm{ER}\left(\Delta \mathrm{CH}_{3} \mathrm{OH} / \triangle \mathrm{CO}\right)$ on the 30 October fire was 0.0209 or 0.0193 using the summation or regression method, respectively. The summation method is intrinsically more sensitive to the duration of the measurements as opposed to peak emissions because each datum is weighted equally. Both methods give similar ERs and we choose the regression method to emphasize measurements collected with high SNR during the most intense periods of combustion.
ERs can be used to calculate EFs expressed as grams of compound emitted per kilogram of biomass burned (on a dry weight basis). A set of ERs obtained at any point during the fire could be used to calculate a set of EFs relevant to the time of the sample. For this study we use fire-averaged ERs (obtained as described above) to calculate a set of fireaveraged EFs for each fire using the carbon mass-balance method (Yokelson et al., 1996, 1999) illustrated by Eq. (1):

$\mathrm{EF}\left(\mathrm{g} \mathrm{kg}^{-1}\right)=F_{\mathrm{C}} \times 1000 \times \frac{\mathrm{MM}_{\mathrm{X}}}{\mathrm{MM}_{\mathrm{C}} \times \frac{\mathrm{C}_{\mathrm{X}}}{\mathrm{C}_{\mathrm{T}}}}$

where $F_{\mathrm{C}}$ is the mass fraction of carbon in the fuel, $\mathrm{MM}_{\mathrm{X}}$ is the molecular mass of compound $\mathrm{X}, \mathrm{MM}_{\mathrm{C}}$ is the molecular mass of carbon $\left(12.011 \mathrm{~g} \mathrm{~mol}^{-1}\right)$, and $\mathrm{C}_{\mathrm{X}} / \mathrm{C}_{\mathrm{T}}$ is the number of emitted moles of compound $\mathrm{X}$ divided by the total number of moles of carbon emitted. $\mathrm{C}_{\mathrm{X}} / \mathrm{C}_{\mathrm{T}}$ can be calculated directly from the fire-averaged ERs and consideration of the number of carbon atoms in a species. This method is most accurate when the mass fraction of carbon in the fuel is precisely known and all the burnt carbon is volatilized and detected. Based on literature values for similar fuels (Susott et al., 1996; Burling et al., 2010) we assumed a carbon fraction of 0.50 by mass (on a dry weight basis) for fuels burned in this campaign. The actual fuel carbon fraction was likely within $5-10 \%$ of this value. Note that EFs scale linearly with the assumed fuel carbon fraction. Total emitted carbon in this study was determined from the sum of the carbon from species quantified from the OP-FTIR spectra. This sum underestimates the actual total carbon by a few percent due to unmeasured carbon leading to a slight, across-the-board overestimate of calculated EFs (Akagi et al., 2011).

Because the emissions from flaming and smoldering processes differ, we use the modified combustion efficiency, or MCE, to describe the relative contribution of each of these combustion processes, where higher MCEs indicate more flaming combustion (Ward and Radke, 1993; Yokelson et al., 1996) Eq. (2):

$\mathrm{MCE}=\frac{\Delta \mathrm{CO}_{2}}{\Delta \mathrm{CO}_{2}+\Delta \mathrm{CO}}$

\subsection{Field campaign site description}

Fort Jackson is located at $34.05^{\circ}$ latitude and $-80.83^{\circ}$ longitude just northeast of Columbia, SC in the southeastern US. The fires took place on 30 October, 1 November, and 2 November 2011 and are hereafter referred to as the Block 6, $9 \mathrm{~b}$, and $22 \mathrm{~b}$ fires, respectively. Information regarding fuels, weather, size, location, etc. for the three prescribed fires sampled in this study can be found in Akagi et al. (2013).

Fort Jackson Army Base lies at the inland edge of the South Carolina coastal plain in the Sandhills ecosystem, which supports a distinctive type of vegetation. The overstory is dominated by two native pine species, longleaf pine (Pinus palustris) and loblolly pine (Pinus taeda), and also 
features turkey oak (Quercus cerris). In low density pine areas the understory has a diverse herbaceous layer with little bluestem (Schizachyrium scoparium) and scrub oak (turkey oak) regeneration. In high density pine areas associated with fire exclusion there is high degree of canopy closure, which results in less understory vegetation and relatively more duff/litter composed primarily of pine needles. In Block $9 \mathrm{~b}$ (burned on 1 November) there was significant growth of farkleberry (Vaccinium arboretum) intermixed with the mature stands of pine. This fire-adapted community typically is burned every $5-10 \mathrm{yr}$ to maintain forest health and also provide suitable army training grounds (www.dnr.sc.gov/cwcs/ pdf/habitat/SandhillsHabitat.pdf), but the plots burned in this study were specifically selected to include stands with no recent history of prescribed fire. Blocks $6,9 \mathrm{~b}$, and $22 \mathrm{~b}$ had not been burned since 1957, 1956, and 2003, respectively. In addition, the plots were ignited under drought conditions in an effort to create a scenario closer to that of a wildfire. Thus, the Fort Jackson fires provide a contrast to the Camp Lejeune fires sampled earlier in this series of studies by Burling et al. (2011), which studied sites burned on a regular basis during a wet spring.

\section{Results and discussion}

\subsection{Three-pronged sampling approach}

Three FTIRs - the OP-FTIR, LAFTIR, and AFTIR - were used at different temporal and spatial scales to provide more complete data on smoke emissions over the duration of the fire. The OP-FTIR successfully sampled smoke generated by ignition activities near the measurement path; post-ignition, wind-blown smoke from the wake of the receding, local flame front; occasional smoke from more distant combustion; and any upwind residual smoldering combustion emissions that were directed through the open path. The OPFTIR initially captured mostly flaming emissions (from ignition of the forest understory) and then a mix of flaming and smoldering emissions that were not entrained in the convection column, see Sect. 3.1.3). These emissions originated in a non-fixed, upwind portion of the burn unit because the fires created sporadic local winds and downdrafts in addition to the light and variable winds that were prevalent during the measurements. The AFTIR sampled flaming emissions mixed with entrained smoldering emissions in the intense, single convection column that was generated by each burn. The convection column is not developed enough for airborne sampling until sufficient fire has been applied to site. Finally, the ground-based LAFTIR system actively located point-sources of RSC smoke after the flame front had passed through the sample area. Our expectation before the experiment was that both ground-based FTIRs would observe much lower MCEs than the AFTIR and that the OP-FTIR data would help us weight the relative contribution of the differ- ent smoldering point sources sampled by the LAFTIR to the overall ground-level smoke layer. However, the RSC point sources were widely separated on these prescribed fires and the wind-blown smoke crossing the OP-FTIR path was also impacted by flaming emissions not sampled by the LAFTIR, especially in the early period of the fire's progression. Additionally, the LAFTIR system often roved to locations whose emissions were not directed towards the OP-FTIR, which in turn often sampled drift smoke whose source was not sampled by the LAFTIR. Because the two instruments often sampled different emissions we could not estimate the contribution of RSC to the ground-level smoke layer, but flaming emissions clearly contributed more than we expected as discussed below. The detailed sampling protocol for each instrument is presented next.

\subsubsection{OP-FTIR}

Unlike the LAFTIR and AFTIR, the OP-FTIR was set up before the burns on a pre-selected portion of the fire perimeter. For each fire the OP-FTIR was positioned to capture the downwind smoke emitted shortly after the fire ignition commenced. Figure 2 shows the burn blocks at Fort Jackson and the relative placement of the OP-FTIR for each fire. After ignition, the OP-FTIR sampled a variety of emissions as detailed next. Figure 3 shows the OP-FTIR time series of MCE and excess CO (ppm) that can be used as indicators of the combustion type and intensity the OP-FTIR observed on each fire. The AFTIR and LAFTIR sampling time periods and fire ignition times are also shown.

During the Block 6 fire, light and variable winds were from the northeast and the OP-FTIR was positioned along the southwest perimeter of the fire area with an optical path of $32.2 \mathrm{~m}$ (Fig. 2a). A backing fire was started at 12:24 local time (LT, EDT) on the southwestern perimeter of the burn block along the same firebreak as the OP-FTIR setup. The heading fire was initiated at the opposite end of the block at 13:35 LT, with more backfires lit to increase the fire intensity at $\sim 15: 20 \mathrm{LT}$. The most intense column of smoke of the day was sampled by AFTIR $\sim 25$ min later around 15:46 LT (Fig. 3a).

For the Block $9 \mathrm{~b}$ fire, light winds (typically $3-4 \mathrm{~m} \mathrm{~s}^{-1}$ ) were from the north and the OP-FTIR was placed on the south side along an east-west road with an optical path of $29.3 \mathrm{~m}$ (Fig. 2b). A backing fire was lit near the OP-FTIR at $\sim 11: 15 \mathrm{LT}$ and produced very heavy smoke with the high intensity reflected in the high starting MCE and high levels of excess CO (Fig. 3b). The headfire was ignited at 13:46 LT.

For the Block 22b fire on 2 November, the winds were from the northeast and the OP-FTIR was placed along the western boundary along a north-south road (optical path of $30.3 \mathrm{~m}$, Fig. 2c) in an effort to capture smoke from both the heading and the backing fires. The heading fires were started around 12:00 LT with the backing fires lit near the open-path setup at approximately 14:00 LT. The OP-FTIR CO peaked 

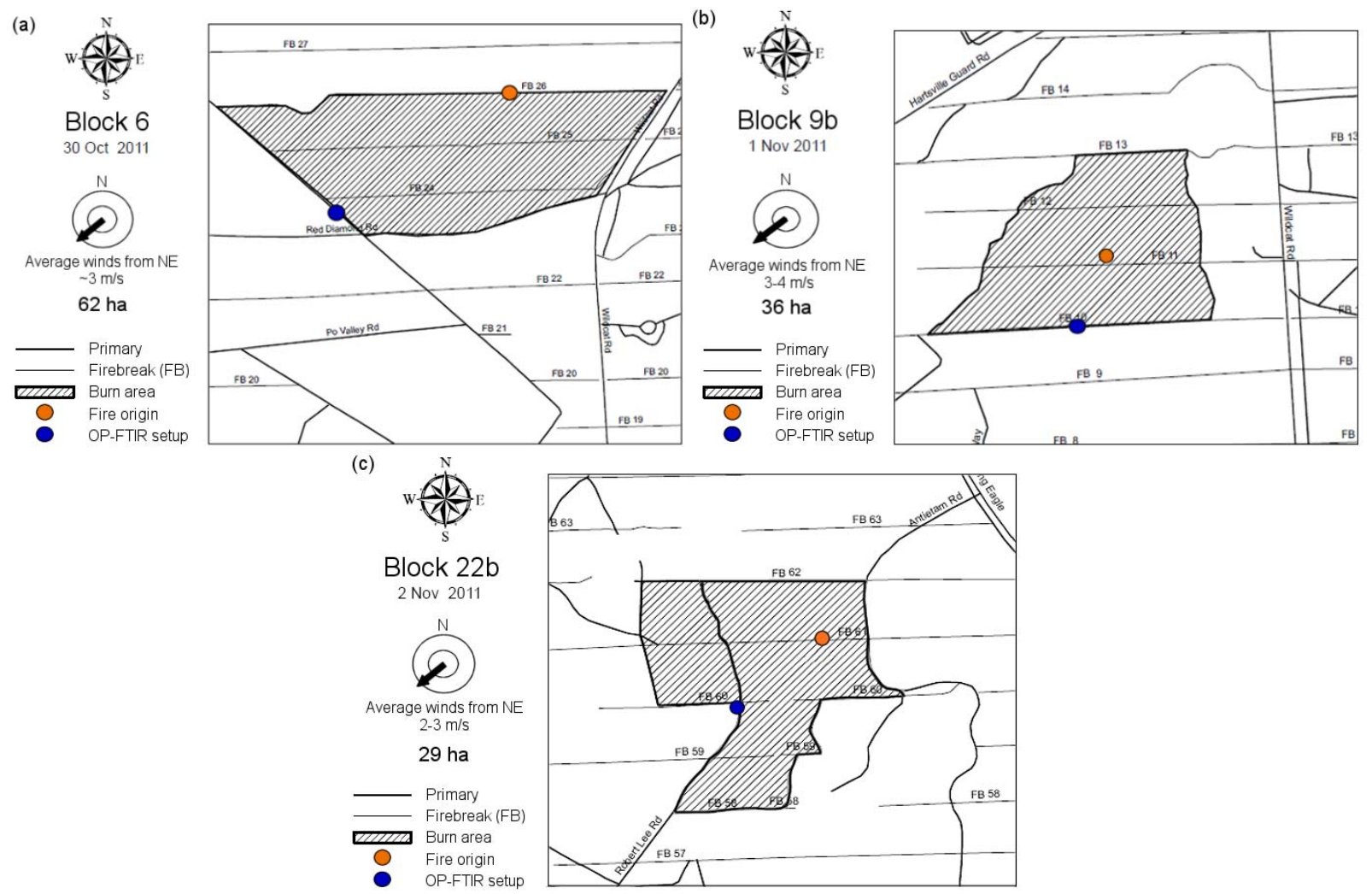

Fig. 2. Detailed burn maps of (a) Block 6, (b) Block 9b, and (c) Block 22b prescribed fires at Fort Jackson, SC. The location of the OP-FTIR is shown as a blue circle. The location where the fire was first lit is shown by the orange circle. Fires were typically lit along firebreaks in a continuous line with the "fire origin" representing where the fire-line was initiated.

$\sim 25$ min later and the AFTIR peaked $\sim 35$ min after that (Fig. 3c).

\subsubsection{AFTIR}

The AFTIR airborne sampling strategy is detailed in Akagi et al. (2013). To measure the initial emissions, lofted smoke less than several minutes old was sampled by penetrating the smoke column 150 to several thousand meters from the flame front (Fig. 1c). The smoke sampled by the AFTIR was produced by flaming combustion of understory and canopy fuels with a significant contribution $(\sim 40 \%$, Yokelson et al., 1996) from smoldering emissions that became entrained in the single, main updraft core. AFTIR sampling periods and peak smoke samples are seen in Fig. 3.

\subsubsection{LAFTIR}

The LAFTIR ground-based sampling protocol was similar to that described in Burling et al. (2011) and Akagi et al. (2013). Backgrounds were acquired before the fire. Ground-based sampling access was sometimes precluded during ignition, but sampling access then continued through late afternoon until the fire was effectively out. During post-ignition access, numerous point sources of RSC were sought out and sam- pled with the LAFTIR system minutes to hours after passage of a flame front. Spot sources of white smoke, mainly produced from pure smoldering combustion, included smoldering stumps, fallen logs, litter layers, etc., and they contributed to a dense smoke layer below the canopy. The LAFTIR sometimes sampled in the vicinity of the OP-FTIR, but frequently roved to other areas. The LAFTIR sampling period for each fire is shown in Fig. 3.

\subsection{MCE, initial emissions, and a comparison of flaming- and smoldering-dominated combustion measured by OP-FTIR}

\subsubsection{MCE and initial emissions}

OP-FTIR fire-average MCEs and EFs are shown in Table 1. The OP-FTIR MCEs across all fires showed minimal variability with a study-average of $0.912 \pm 0.004$ compared to the LAFTIR $(0.842 \pm 0.046)$ and AFTIR $(0.929 \pm 0.008)$. The average MCE for full fires burning SE US DoD fuels in the lab was $0.937 \pm 0.024$ (Burling et al., 2010). The intermediate OP-FTIR MCE is consistent with roughly equal amounts of smoldering and flaming emissions being transported to the OP-FTIR path (Sect. 3.1.1). 10 out of 13 OPFTIR species showed consistent EFs across all three fires 

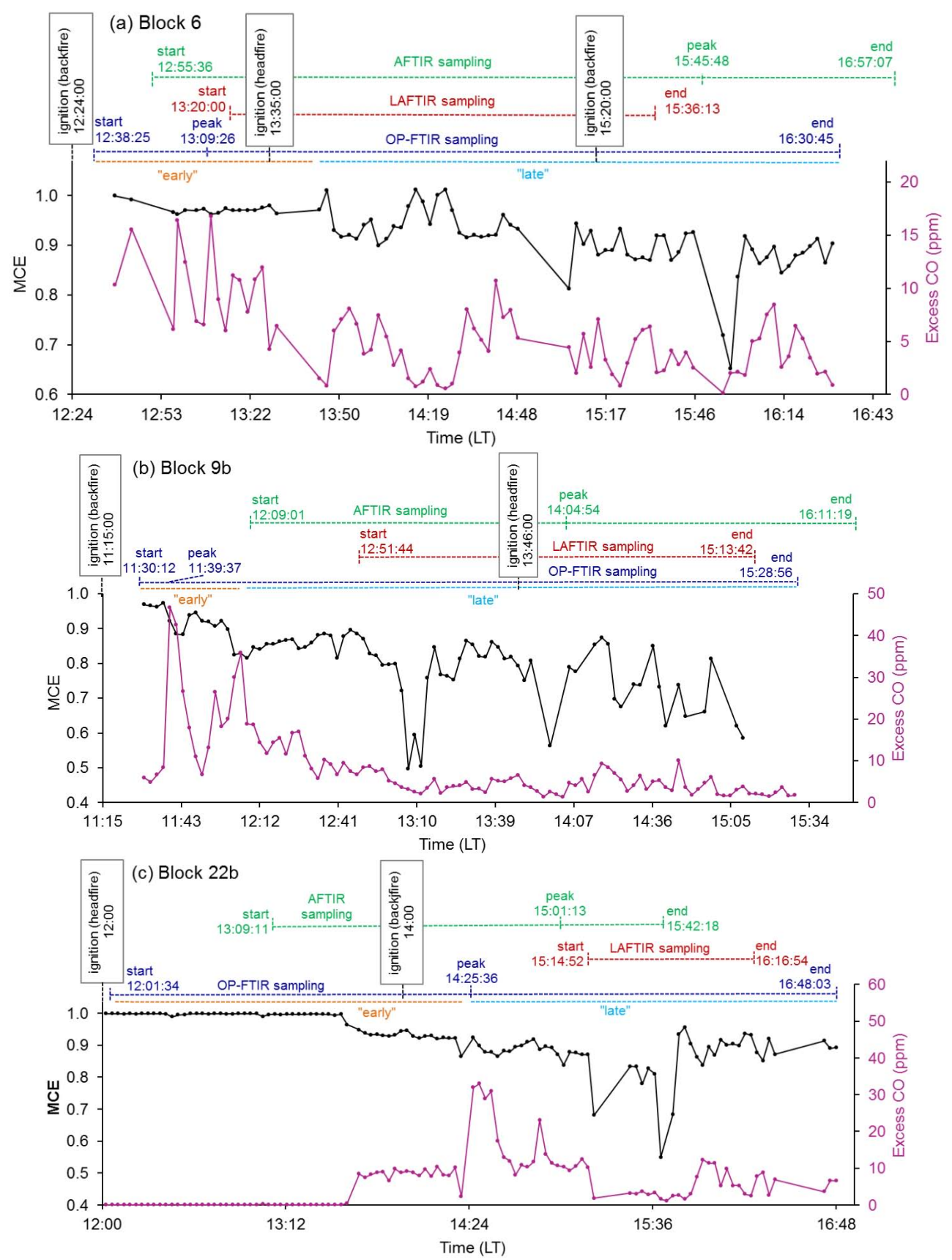

Fig. 3. MCE (black) and excess CO (ppm, pink) time series from OP-FTIR on the three Fort Jackson fires. Above the time series, AFTIR (green), LAFTIR (red), and OP-FTIR (dark blue) sampling time frames are shown to denote the start and end of measurement collection and when the "peak" intensity signal was observed from a given measurement platform. "Early" and "late" periods of OP-FTIR sampling are denoted in orange and light blue, respectively. Ignition times are shown in black to mark the lighting of headfires and backfires.

(less than $18.6 \%$ fire-average relative standard deviation, or RSD). The major exceptions were acetylene (96.4\% RSD) and the two nitrogen-containing compounds, $\mathrm{HCN}(65.3 \%$ $\mathrm{RSD})$ and $\mathrm{NH}_{3}(48.6 \% \mathrm{RSD})$. The high variability in the latter two compounds is not surprising since the highly variable nitrogen content of biomass fuel can have a large influence on the emissions of N-containing species (Burling et al., 2011).
High variability in acetylene has been observed in the literature and is likely attributed to the fact that $\mathrm{C}_{2} \mathrm{H}_{2}$ can be produced from both flaming and smoldering combustion and often shows little dependence on MCE (Burling et al., 2010; Lobert et al., 1991; Yokelson et al., 2011). 
Table 1. MCE (bolded) and EFs $\left(\mathrm{g} \mathrm{kg}^{-1}\right)$ for three pine understory burns measured by OP-FTIR.

\begin{tabular}{llrrrrr}
\hline & & Block 6 & Block 9b & Block 22b & Average & Std dev \\
\cline { 3 - 7 } MCE & & $\mathbf{0 . 9 1 7}$ & $\mathbf{0 . 9 1 1}$ & $\mathbf{0 . 9 0 9}$ & $\mathbf{0 . 9 1 2}$ & $\mathbf{0 . 0 0 4}$ \\
\hline Species & Formula & & & & & \\
\hline Carbon Dioxide & $\mathrm{CO}_{2}$ & 1652.8 & 1642.5 & 1645.3 & 1646.9 & 5.3 \\
Carbon Monoxide & $\mathrm{CO}$ & 94.8 & 102.1 & 104.9 & 100.6 & 5.2 \\
Methane & $\mathrm{CH}_{4}$ & 2.62 & 2.70 & 2.72 & 2.68 & 0.05 \\
Ethylene & $\mathrm{C}_{2} \mathrm{H}_{4}$ & 1.67 & 1.58 & 1.69 & 1.65 & 0.06 \\
Ammonia & $\mathrm{NH}_{3}$ & 0.54 & 0.38 & 0.97 & 0.63 & 0.30 \\
Hydrogen Cyanide & $\mathrm{HCN}_{\text {Formaldehyde }}$ & 2.11 & 0.78 & - & 1.44 & 0.94 \\
Acetic Acid & $\mathrm{HCHO}$ & 2.31 & 2.48 & 2.69 & 2.49 & 0.19 \\
Formic Acid & $\mathrm{CH}_{3} \mathrm{COOH}$ & 2.96 & 3.88 & 2.76 & 3.20 & 0.60 \\
Methanol & $\mathrm{HCOOH}$ & 0.40 & 0.38 & 0.31 & 0.36 & 0.04 \\
Acetylene & $\mathrm{CH}_{3} \mathrm{OH}$ & 2.09 & 2.00 & 1.88 & 1.99 & 0.11 \\
Carbonyls as glyoxal & $\mathrm{C}_{2} \mathrm{H}_{2}$ & 0.81 & 0.15 & - & 0.48 & 0.46 \\
Furan & $\mathrm{C}_{2} \mathrm{H}_{2} \mathrm{O}_{2}$ & 1.60 & 2.01 & - & 1.80 & 0.29 \\
Sum NMOC $^{\mathrm{b}}$ & $\mathrm{C}_{4} \mathrm{H}_{4} \mathrm{O}$ & - & 0.48 & - & 0.48 & - \\
\hline
\end{tabular}

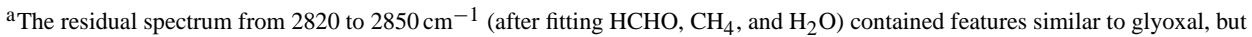
shifted by several wavenumbers. The feature may have been due to a mixture of oxygenated compounds (most likely carbonyls), but was analyzed using the glyoxal IR cross-section (Profeta et al., 2011). ${ }^{b}$ Non-methane organic compounds.

\subsubsection{Comparison of flaming- and smoldering-dominated combustion sampled by OP-FTIR}

Fire-average EFs are important when assessing overall fire characteristics or when comparing to other fire-average $\mathrm{EF}$ in the literature. That being said, the drop in OP-FTIR MCE seen partway through each Fort Jackson fire (Fig. 3) suggests that EF computed separately for "early" and "late" time blocks would be mainly indicative of flaming- and smoldering-dominated combustion, respectively. In fact, the calculation of OP-FTIR EF for "early" and "late" periods did inform the comparison to EF measured from other platforms. It should be noted that not all fire measurements show a fast transition between high and low MCE (Yokelson et al., 1996) and the division between "early" and "late" can be indistinct. However, this informal separation is one useful way to probe the dynamic mix of flaming and smoldering combustion and compare to other platforms. Delineation between "early" and "late" are seen for the three fires in Fig. 3. As an example, on the Block 6 fire, "early" was defined from the first OP-FTIR sample (12:38:25 LT) until a noticeable drop in MCE is observed (13:47:00 LT, upper trace, black, Fig. 3a). This signifies a change in the composition of the sampled smoke from mostly flaming to more smoldering combustion. Emission factors for "early" and "late" smoke measured by OP-FTIR from the Fort Jackson fires are shown in Table 2. This shift from flaming- to smoldering-dominated combustion is also noted in the ER plots for several species, including $\mathrm{CO}$ and methanol (Fig. 4). Both species are primarily produced from smoldering combustion and thus, a higher ratio of $\Delta \mathrm{CO} / \Delta \mathrm{CO}_{2}$ and $\Delta \mathrm{CH}_{3} \mathrm{OH} / \Delta \mathrm{CO}$ was observed when sampling "late" smoke that had a greater contribution from un-lofted RSC ("late" data are shown in blue). $\mathrm{CO}$ had a large EF range, with $\mathrm{EF}(\mathrm{CO})$ "late" being almost twice as large as $\mathrm{EF}(\mathrm{CO})$ "early". While we generally observe higher OP-FTIR EF for some smoldering compounds late in the fire associated with lower MCE, we note that this trend was not consistently observed across all fires and platforms. Additionally, we observe mixed, somewhat anomalous results likely rooted in fuel differences for other species such as ammonia, ethylene, acetic acid, formaldehyde, and formic acid (Table 2). On the Block $9 b$ fire, the $\mathrm{EF}$ for $\mathrm{NH}_{3}$ and $\mathrm{CH}_{3} \mathrm{COOH}$ are twice as large for the early flaming dominated OP-FTIR samples as they are for the later smoldering dominated samples, despite the fact that these compounds are well-known to be associated with smoldering emissions. It is possible that the OP-FTIR may be relatively more influenced by recirculated emissions from burning live fuels early in the fire.

\subsection{OP-FTIR data compared with LAFTIR and AFTIR FTIR platforms}

It is of interest to compare the emission factors from all three FTIRs employed during the Fort Jackson burns since each FTIR had a different spatial and temporal perspective on the overall combustion emissions. Figure 5 shows a side-by-side comparison of OP-FTIR, LAFTIR, and AFTIR fire-averaged emission factors from all three Fort Jackson fires. The study-average MCEs were $0.929 \pm 0.008$, $0.912 \pm 0.004$, and $0.841 \pm 0.046$ for the AFTIR, OP-FTIR, 
Table 2. MCE (bolded) and EFs $\left(\mathrm{g} \mathrm{kg}^{-1}\right)$ for select compounds measured during "early" and "late" blocks by OP-FTIR. Fire-averaged EF from the AFTIR and LAFTIR (Akagi et al., 2013) are also shown.

\begin{tabular}{|c|c|c|c|c|c|c|}
\hline Fire & & & AFTIR & $\begin{array}{c}\text { OP-FTIR } \\
\text { (“early”) }\end{array}$ & $\begin{array}{r}\text { OP-FTIR } \\
\text { ("late") }\end{array}$ & LAFTIR \\
\hline \multirow[t]{13}{*}{ Block 6} & MCE & & 0.932 & 0.927 & 0.869 & 0.876 \\
\hline & Carbon Dioxide & $\mathrm{CO}_{2}$ & 1674 & 1673.2 & 1574.8 & 1554 \\
\hline & Carbon Monoxide & $\mathrm{CO}$ & 78 & 83.7 & 150.8 & 140 \\
\hline & Methane & $\mathrm{CH}_{4}$ & 1.74 & 2.16 & 2.39 & 5.20 \\
\hline & Ethylene & $\mathrm{C}_{2} \mathrm{H}_{4}$ & 1.21 & 1.75 & 1.00 & 0.89 \\
\hline & Ammonia & $\mathrm{NH}_{3}$ & 0.11 & 0.50 & 0.61 & 0.09 \\
\hline & Hydrogen Cyanide & $\mathrm{HCN}$ & 0.74 & 1.86 & - & 0.95 \\
\hline & Formaldehyde & $\mathrm{HCHO}$ & 1.87 & 2.25 & 1.55 & 1.79 \\
\hline & Acetic Acid & $\mathrm{CH}_{3} \mathrm{COOH}$ & 1.24 & 2.71 & 2.26 & 1.03 \\
\hline & Formic Acid & $\mathrm{HCOOH}$ & 0.08 & 0.41 & 0.24 & - \\
\hline & Methanol & $\mathrm{CH}_{3} \mathrm{OH}$ & 1.18 & 1.66 & 1.99 & 2.35 \\
\hline & Acetylene & $\mathrm{C}_{2} \mathrm{H}_{2}$ & 0.35 & 0.74 & 0.50 & 0.25 \\
\hline & Carbonyls as glyoxal* & $\mathrm{C}_{2} \mathrm{H}_{2} \mathrm{O}_{2}$ & - & 1.40 & 1.34 & - \\
\hline \multirow[t]{14}{*}{ Block 9b } & MCE & & 0.919 & 0.923 & 0.849 & 0.858 \\
\hline & Carbon Dioxide & $\mathrm{CO}_{2}$ & 1643 & 1665.6 & 1545.3 & 1496 \\
\hline & Carbon Monoxide & $\mathrm{CO}$ & 92 & 89.0 & 174.4 & 158 \\
\hline & Methane & $\mathrm{CH}_{4}$ & 2.08 & 2.41 & 2.11 & 11.50 \\
\hline & Ethylene & $\mathrm{C}_{2} \mathrm{H}_{4}$ & 1.23 & 1.59 & 0.98 & 1.53 \\
\hline & Ammonia & $\mathrm{NH}_{3}$ & 0.13 & 0.62 & 0.29 & 0.23 \\
\hline & Hydrogen Cyanide & $\mathrm{HCN}$ & 0.82 & 0.61 & - & 0.85 \\
\hline & Formaldehyde & $\mathrm{HCHO}$ & 2.11 & 2.16 & - & 2.42 \\
\hline & Acetic Acid & $\mathrm{CH}_{3} \mathrm{COOH}$ & 0.75 & 3.94 & 2.03 & 3.84 \\
\hline & Formic Acid & $\mathrm{HCOOH}$ & 0.09 & 0.32 & 0.31 & - \\
\hline & Methanol & $\mathrm{CH}_{3} \mathrm{OH}$ & 1.45 & 1.69 & 1.69 & 6.42 \\
\hline & Acetylene & $\mathrm{C}_{2} \mathrm{H}_{2}$ & 0.24 & 0.13 & - & 0.22 \\
\hline & Carbonyls as glyoxal* & $\mathrm{C}_{2} \mathrm{H}_{2} \mathrm{O}_{2}$ & - & 1.75 & - & - \\
\hline & Furan & $\mathrm{C}_{4} \mathrm{H}_{4} \mathrm{O}$ & 0.20 & 0.42 & - & - \\
\hline \multirow[t]{10}{*}{ Block 22b } & MCE & & 0.935 & 0.935 & 0.897 & 0.789 \\
\hline & Carbon Dioxide & $\mathrm{CO}_{2}$ & 1679 & 1701.4 & 1630.5 & 1305 \\
\hline & Carbon Monoxide & $\mathrm{CO}$ & 74 & 75.5 & 118.9 & 222 \\
\hline & Methane & $\mathrm{CH}_{4}$ & 2.01 & 1.53 & 1.94 & 10.34 \\
\hline & Ethylene & $\mathrm{C}_{2} \mathrm{H}_{4}$ & 0.94 & 1.49 & 1.12 & 1.25 \\
\hline & Ammonia & $\mathrm{NH}_{3}$ & 0.14 & 0.87 & 0.66 & 0.33 \\
\hline & Formaldehyde & $\mathrm{HCHO}$ & 1.70 & - & 1.86 & 2.51 \\
\hline & Acetic Acid & $\mathrm{CH}_{3} \mathrm{COOH}$ & 1.25 & 2.17 & 1.89 & 2.42 \\
\hline & Formic Acid & $\mathrm{HCOOH}$ & 0.11 & 0.20 & 0.22 & - \\
\hline & Methanol & $\mathrm{CH}_{3} \mathrm{OH}$ & 1.16 & 1.12 & 1.33 & 3.60 \\
\hline
\end{tabular}

*The residual spectrum from 2820 to $2850 \mathrm{~cm}^{-1}$ (after fitting $\mathrm{HCHO}, \mathrm{CH}_{4}$, and $\mathrm{H}_{2} \mathrm{O}$ ) contained features similar to glyoxal, but shifted by several wavenumbers. The feature may have been due to a mixture of oxygenated compounds (most likely carbonyls), but was analyzed using the glyoxal IR cross-section (Profeta et al., 2011).

and LAFTIR platforms, respectively (calculated from Table 2). The MCEs from the AFTIR and LAFTIR indicate larger contributions from flaming and smoldering combustion, respectively. We observe a general trend for some smoldering species whose emissions depend more strongly on MCE than fuel type (e.g. $\mathrm{CH}_{4}, \mathrm{CH}_{3} \mathrm{OH}$, furan) - namely: $\mathrm{EF}(\mathrm{AFTIR})<\mathrm{EF}(\mathrm{OP}-\mathrm{FTIR})<\mathrm{EF}(\mathrm{LAFTIR})$, which is consistent with the decreasing trend in FTIR fire-averaged
MCEs. However, exceptions exist when considering all fires and all platforms. For nitrogen compounds whose emissions are typically more fuel dependent (e.g. $\mathrm{HCN}, \mathrm{NH}_{3}$ ), a general $\mathrm{EF}(\mathrm{AFTIR}<\mathrm{EF}(\mathrm{LAFTIR})<\mathrm{EF}(\mathrm{OP}-\mathrm{FTIR})$ trend was observed.

It can be helpful to now combine and compare data from other measurement platforms (LAFTIR and AFTIR) with OP-FTIR data broken down into flaming-/smoldering- 

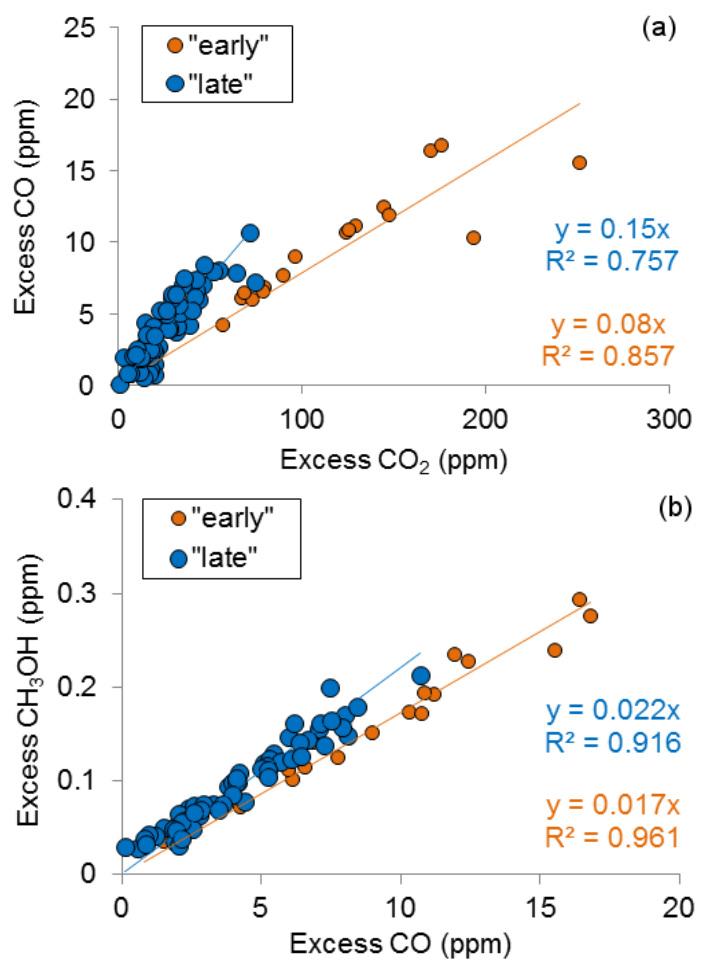

Fig. 4. ER plots of (a) $\Delta \mathrm{CO} / \Delta \mathrm{CO}_{2}$ and (b) $\Delta \mathrm{CH}_{3} \mathrm{OH} / \Delta \mathrm{CO}$ from the Block 6 ( 30 October) fire with two trend-lines shown: samples collected "early" in the fire are shown as orange circles and those collected "late" in the fire are shown as blue circles. Different trends observed "early" and "late" in the fire's progression imply changes in the sampled smoke over time and a decrease in MCE.

dominated phases to further investigate general trends observed in Fig. 5. Table 2 includes a detailed comparison of emissions from different platforms and different fires, with OP-FTIR EF divided into "early" and "late" sampling periods. These data are visually represented in Fig. 6. The OPFTIR ("early") MCE is similar to the AFTIR MCE on all fires. This is expected, since the smoke observed by the OPFTIR during the initial phase of the fire was mostly flaming emissions. Alternately, the OP-FTIR ("late") MCE is similar to the LAFTIR MCE on the Block 6 and Block 9b fires, which is also expected since the OP-FTIR ("late") phase sampled mostly smoldering debris after passage of the flame front. However, beyond these similarities no consistent trend is seen. For instance, the values for LAFTIR $\mathrm{CH}_{4}$ are 2-5 times higher than the values for OP-FTIR "late" at similar MCE. The data are highly variable and the passively-sampled OP-FTIR values may be less biased than the LAFTIR values. Some of the EF that were higher for OP-FTIR compared to the other two platforms are also known as "sticky" compounds that can be difficult to sample in closed-cell systems $\left(\mathrm{NH}_{3}\right.$ and $\left.\mathrm{HCOOH}\right)$. However, small to no losses of these species were observed during 120-180 s storage in the closed cells and the residence times in the coated/Teflon inlets are only 1-2 s. Further, losses on the cell walls were measured and corrected for in both closed cell FTIR systems according to a protocol developed by Yokelson et al. (2003) who directly compared AFTIR and OP-FTIR systems in the same well-mixed laboratory smoke samples. If the passivation corrections were accurate, then the higher study-average EF by OP-FTIR for some species in this work may largely be due to sampling emissions from a different mix of fuels. This idea is supported by the fact that EFs for $\mathrm{HCN}, \mathrm{HCHO}$, and $\mathrm{C}_{2} \mathrm{H}_{4}$, which are generally smoldering compounds that do not suffer from wall losses, are also higher in OP-FTIR than the closed cell systems. In addition, the $\mathrm{NH}_{3} \mathrm{EFs}$ agree well for the LAFTIR and OP-FTIR "late" period on one fire (Block 9b). Nevertheless, we acknowledge that open-path measurements are inherently immune to sampling losses for such species and if the closed cell correction factors are too small, then fires may emit more $\mathrm{NH}_{3}$ or $\mathrm{HCOOH}$ than our previous closed-cell measurements indicate (Akagi et al., 2011). Regardless of the reason for the study-average differences between the FTIRs (e.g. fuel differences, temperature differences (Aan de Brugh et al., 2012), sampling issues (Norman et al., 2009)), the EFs from the OP-FTIR show that flaming influenced the ground level smoke layer.

\subsection{OP-FTIR comparisons with the literature}

We can compare the OP-FTIR EF with those from a study that employed a similar open-path FTIR to measure biomass burning emissions from South African savanna fires (Wooster et al., 2011). The fire-averaged MCE and $\Delta \mathrm{CO} / \Delta \mathrm{CO}_{2}$, respectively, from Wooster et al. (2011) $(0.913 \pm 0.026$ and 0.095$)$ are similar to those in this work $(0.912 \pm 0.004$ and 0.095$)$. This similarity in fire-average $\mathrm{MCE}$ and $\Delta \mathrm{CO} / \Delta \mathrm{CO}_{2}$ is surprising considering pineunderstory and savanna fuels are intrinsically different and have been measured from airborne platforms at different $\mathrm{MCE}$ and $\Delta \mathrm{CO} / \Delta \mathrm{CO}_{2}$ (pine-understory: $0.931 \pm 0.016$ and 0.074; savanna: $0.944 \pm 0.012$ and 0.059; Akagi et al., 2011, 2013). Savannas are usually dominated by fine fuels that burn at high combustion efficiency (Akagi et al., 2011) and do not often include large diameter fuels highly susceptible to prolonged smoldering. Temperate pine understory ecosystems often have more dead/down debris and below-ground fuels like organic soils that tend to burn by smoldering and/or RSC although that is minimized in prescribed fires. The Wooster et al. (2011) fires were not sampled by an airborne platform, thus, we cannot compare both OP-FTIR and AFTIR MCEs between the studies. We can compare emissions for several species from this work and Wooster et al. (2011) (Fig. 7). Emission factors from this work are all within the natural variability of $\mathrm{EF}$ (computed as the 1- $\sigma$ standard deviation of fire-averaged EF reported by Wooster et al., 2011), except for $\mathrm{NH}_{3}$. As mentioned in Sect. 3.2.1, multiple factors can affect ammonia emissions, the most important factor being the nitrogen content of the fuel. Measurements in Wooster 


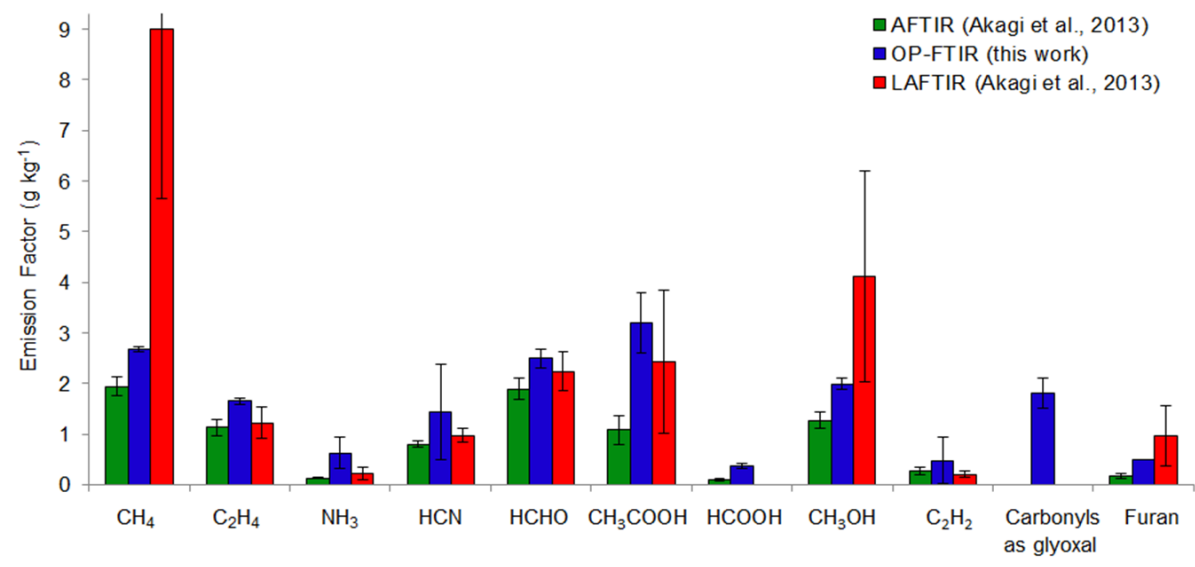

Fig. 5. Side-by-side comparison of study-average emission factors between the AFTIR (green), OP-FTIR (blue), and LAFTIR (red) FTIRs employed during the Fort Jackson campaign. The EFs and error bars represent the average EF and 1- $\sigma$ standard deviation over all three of the Fort Jackson fires, respectively.

et al. (2011) were acquired at Kruger National Park where elephant dung is a major fuel component. Dung is known to have a higher nitrogen content compared with other biomass types (Christian et al., 2007; Keene et al. 2006). While the $\mathrm{N}$ content of fuels sampled in this work and in Wooster et al (2011) is unknown, higher fuel $\mathrm{N}$ could explain why $\mathrm{EF}\left(\mathrm{NH}_{3}\right)$ was significantly higher in Wooster et al. (2011).

\subsection{Estimating fire-line exposure to air toxics}

Smoke has numerous and varied possible health effects, especially for fire-line workers who are subjected to it on a routine basis. Quantification, of ground-level concentrations over the duration of a prescribed fire is one part of assessing the risk. The measured exposures can then be compared to laws and guidelines that estimate potentially harmful levels of toxins. Average concentrations over time and peak exposures are both of concern: in the US, the Occupational Safety and Health Administration (OSHA) sets legal exposure limits known as permissible exposure limits (PELs) and short-term exposure limits (STELs) for these two cases, respectively. A PEL is a time-weighted average (TWA) concentration not to be exceeded for routine $8 \mathrm{~h}$ exposure while a STEL should not be exceeded for any $15-30 \mathrm{~min}$ period. The National Institute of Occupational Safety and Health (NIOSH) provide Recommended Exposure Limits, or RELs, as TWA concentrations for an $8 \mathrm{~h}$ or $10 \mathrm{~h}$ workday. NIOSH also reports STELs as a 15 min maximum exposure. NIOSH limits, being guidelines, are often more conservative than those enforced by OSHA (Sharkey, 1997). In addition to NIOSH, the American Conference of Industrial Hygienists (ACGIH) sets exposure guidelines known as Threshold Limit Values (TLVs). The ACGIH TLV is an $8 \mathrm{~h}$ TWA and the TLV STEL is a 15 min maximum exposure. In our analysis we report a range when more than one exposure limit/guideline is available.
Table 3 shows measured TWA burn-average and peak exposures for $\mathrm{CO}$ and $\mathrm{HCHO}$ from this work, other works (Reinhardt and Ottmar, 2004), and the recommended TWA $(8 \mathrm{~h})$ and STEL exposure ranges. We first compare OP-FTIR burn-average TWA concentrations to those from Reinhardt and Ottmar (2004), who report a frequency distribution of fire-line exposures as a cumulative percent of sampled firefighters measured from prescribed burns in the Northwest. The CO burn-average mixing ratio exposure for firefighters in the 50th percentile from Reinhardt and Ottmar (2004) was slightly higher (by $8.6 \%$ ) than the burn-average concentration measured in this work, while their HCHO 50th percentile concentration was approximately a factor of two lower than in our work. Location, fuel, weather, and fuel moisture are just some of the variables that could have created very different burn conditions between our study and that of Reinhardt and Ottmar (2004). OP-FTIR burnaveraged exposures can also be compared with recommended TWA exposures. Our burn-average $\Delta \mathrm{CO}$ was below all the recommended exposure levels while our burnaverage $\triangle \mathrm{HCHO}$ was near the lower end of exposure guidelines (0.016-0.75 ppm range). Thus, Fort Jackson $\Delta \mathrm{CO}$ and $\triangle \mathrm{HCHO}$ did not exceed OSHA guidelines suggesting that prolonged exposures were a limited problem for these compounds during the Fort Jackson fires.

The average peak mixing ratios for $\mathrm{CO}$ and $\mathrm{HCHO}$ measured by the OP-FTIR and LAFTIR for the three fires and the recommended STEL (15-min) exposure ranges are also shown in Table 3. OP-FTIR peak CO levels are a factor of 20 lower than the peak point exposures measured by Reinhardt and Ottmar (2004); which are 3.6 times lower than LAFTIR peak $\Delta \mathrm{CO}$ point values. OP-FTIR $\Delta \mathrm{CO}$ and $\Delta \mathrm{HCHO}$ peak mixing ratios fall below the range of recommended STEL mixing ratios, but the LAFTIR peak mixing ratios exceed CO and HCHO STELs by factors of 3.2 and 3.8, respectively. While these exceedances are important, we note that 


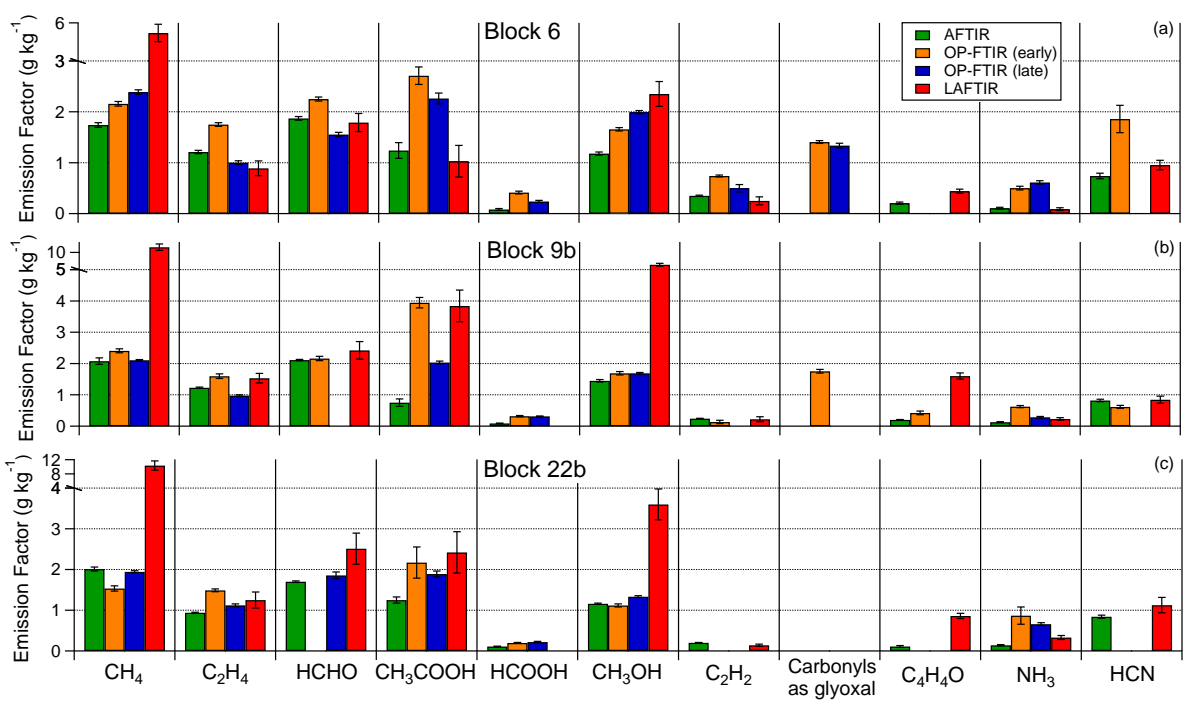

Fig. 6. Emission factors $\left(\mathrm{g} \mathrm{kg}^{-1}\right)$ measured by the AFTIR (green), OP-FTIR, and LAFTIR (red) from the three Fort Jackson fires: (a) Block 6, (b) Block 9b, and (c) Block 22b. The OP-FTIR EF have been broken down into "early" (orange) and "late" (blue) as shown in Fig. 3. Error bars represent the relative uncertainty in the EF. A break has been added in the uppermost $y$ axis EF values that applies only to $\mathrm{CH}_{4}$ and $\mathrm{CH}_{3} \mathrm{OH}$, when applicable.

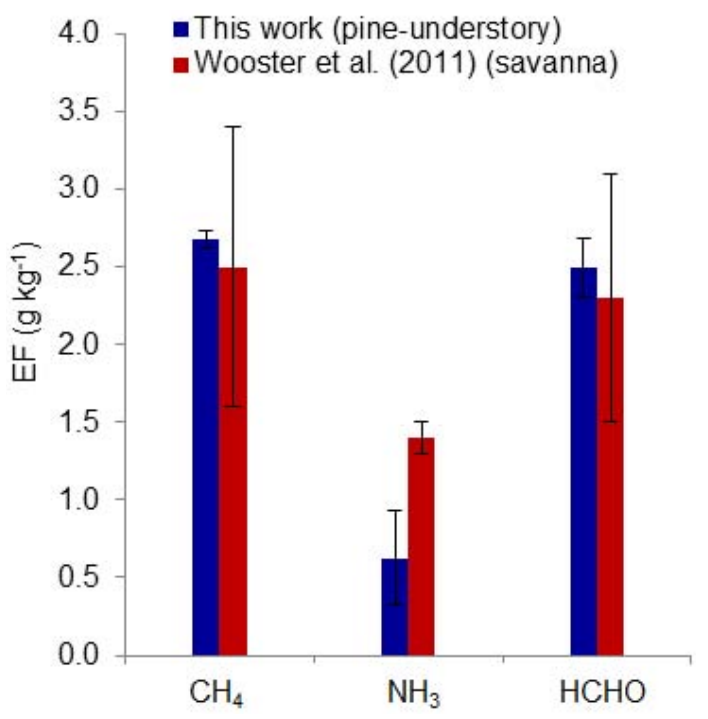

Fig. 7. Comparison of emission factors from this work (blue) and Wooster et al. (2011) (red). EF from this work have been slightly recalculated using a similar mass balance of carbon as dictated by measured species from Wooster et al. (2011), and are thus slightly different than EF shown in Table 1.

LAFTIR values represent a mostly avoidable upper limit, as these mixing ratios were measured by placing the sample line less than $1 \mathrm{~m}$ from smoldering point sources.

Thus far we have limited our discussion of air toxins to $\mathrm{CO}$ and $\mathrm{HCHO}$, though many others exist. Exposure to the other air toxins not measured by the OP-FTIR can be estimated using normalized excess mixing ratios $(\Delta \mathrm{X} / \Delta \mathrm{CO}$ where
" $\mathrm{X}$ " is an air toxin) measured in other studies and multiplying by the OP-FTIR burn-average CO. Exposure estimates have previously been derived this way by Austin (2008) who used published EFs and ceiling limits to calculate "hazard ratios". We use a slightly different approach: we estimate TWA and peak exposures of high risk compounds using a recent comprehensive set of pine-understory prescribed fire emission ratios from Yokelson et al. (2013) and multiply those ER by the OP-FTIR burn-average and peak $\triangle \mathrm{CO}$. For air toxins measured both by OP-FTIR and Yokelson et al. (2013) we can "test" this approach by comparing "estimated" vs. "measured" exposures (for $\mathrm{HCHO}, \mathrm{CH}_{3} \mathrm{OH}, \mathrm{NH}_{3}$, see Table A2 in Appendix A). In most cases the estimated mixing ratios are lower than the measured mixing ratios by up to $65 \%$, except for $\mathrm{HCHO}$ and $\mathrm{NH}_{3}$ measured by the LAFTIR; e.g., the greatest deviation from 1 was the estimated/measured value of 6.60 for the $\mathrm{NH}_{3}$ LAFTIR peak exposure. Given such a high ratio (based on comparison to AFTIR measurements from 2010) it is clear that this estimation technique is less applicable for $\mathrm{N}$-containing compounds since their emissions depend strongly on fuel $\mathrm{N}$ (Burling et al., 2011). It is also important to note that the emissions data from Yokelson et al. (2013) are mostly for the 2010 pine understory prescribed fires at Camp Lejeune that were lit after a wet spring versus older growth stands lit after a prolonged drought in this work. Excluding the one anomalously high $\mathrm{NH}_{3}$ ratio mentioned above, the average estimated/measured ratio and 1- $\sigma$ standard deviation is $0.69 \pm 0.38$. Thus, smoke is variable, but this method is still useful to estimate exposures for unmeasured compounds of interest. 
Table 3. Average TWA and peak exposures measured in this work and other studies and recommended TWA and peak exposures.

\begin{tabular}{|c|c|c|}
\hline & $\mathrm{CO}(\mathrm{ppm})$ & $\mathrm{HCHO}(\mathrm{ppm})$ \\
\hline \multicolumn{3}{|l|}{ Average TWA exposures } \\
\hline $\begin{array}{l}\text { OP-FTIR } \\
\text { (burn-average) }^{\mathrm{a}, \mathrm{b}}\end{array}$ & 6.351 & $0.147^{\mathrm{c}}$ \\
\hline $\begin{array}{l}\text { Reinhardt and Ottmar (2004) } \\
\text { (burn-average, 50th percentile) }^{\mathrm{d}}\end{array}$ & 6.9 & 0.075 \\
\hline $\begin{array}{l}\text { Reinhardt and Ottmar (2004) } \\
\text { (burn-average, 90th percentile) }^{\mathrm{d}}\end{array}$ & 23 & 0.18 \\
\hline $\begin{array}{l}\text { Recommended TWA } \\
\text { ( } 8 \mathrm{~h} \text { average) exposure range }\end{array}$ & $25-50^{\mathrm{e}}$ & $0.016-0.75^{\mathrm{f}}$ \\
\hline \multicolumn{3}{|l|}{ Peak exposures } \\
\hline OP-FTIR $(\max )^{\mathrm{a}, \mathrm{g}}$ & 32.16 & 0.825 \\
\hline LAFTIR $(\max )^{\mathrm{a}, \mathrm{g}}$ & 641.6 & 7.665 \\
\hline Reinhardt and Ottmar (2004) (max) & $>179$ & 1.460 \\
\hline $\begin{array}{l}\text { Recommended STEL } \\
(15 \mathrm{~min}) \text { peak exposure range }\end{array}$ & $200^{\mathrm{h}}$ & $0.1-2.0^{\mathrm{i}}$ \\
\hline
\end{tabular}

${ }^{\text {a }}$ Reported as excess mixing ratios. Absolute values will be slightly higher to account for background concentrations. ${ }^{\mathrm{b}}$ The time at the prescribed burns averaged $4: 13 \mathrm{~h}$ (range $\sim 4-5 \mathrm{~h}$ ). ${ }^{\mathrm{c}}$ Since we do not report HCHO measured from the start to end of the Fort Jackson fires, this value was estimated as ER $(\mathrm{HCHO} / \mathrm{CO}) \times$ OP-FTIR (burn-average) $\Delta \mathrm{CO} .{ }^{\mathrm{d}}$ The time at the prescribed burns averaged $7 \mathrm{~h}$ (range $2-13 \mathrm{~h}$ ). ${ }^{\mathrm{e}}$ Low and high CO values represent ACGIH TWA TLV and OSHA TWA PEL, respectively. ${ }^{\mathrm{f}}$ Low and high HCHO values represent NIOSH TWA REL and OSHA TWA PEL, respectively.

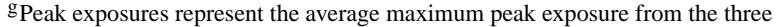
different fires measured. ${ }^{\mathrm{h}}$ NIOSH ceiling and OSHA STEL $(5 \mathrm{~min}) .{ }^{\mathrm{i}}$ Low and high values represent NIOSH STEL and OSHA STEL, respectively.

Based on this methodology we present estimated exposures to many air toxins not measured in this work, but reported in Yokelson et al. (2013) (Table 4). All of the species listed in Table 4 are designated as hazardous air pollutants, or harmful or potentially harmful constituents in tobacco smoke as noted by Yokelson et al. (2013). Our estimated fire-line TWA exposures based on OP-FTIR burn average $\mathrm{CO}$ are significantly lower than recommended TWA exposure limits (a factor of 10 lower at the least), suggesting that reasonably cautious personnel on the Fort Jackson fires likely did not exceed individual recommended exposure limits for the hazardous compounds listed in Table 4. Even estimated peak exposures based on LAFTIR peak $\mathrm{CO}$ were lower than recommended STELs except for acrolein and HCN, which exceeded STELs by factors of 3.7 and 1.2 , respectively. We also show estimated exposures divided by the recommended TWA exposure limits, or $E_{\mathrm{x}}$, where $\mathrm{X}$ is a given compound of interest. $E_{\mathrm{X}}$ can be used to calculate a unitless irritant exposure mixture term $E_{\mathrm{m}}$, where $E_{\mathrm{m}}=E_{x 1}+E_{x 2}+E_{x 3+} \ldots$ (Reinhardt and Ottmar, 2004). For example, $E_{\mathrm{X}}$ for compounds such as acrolein and formaldehyde can be summed and if $E_{\mathrm{m}}$ exceeds 1 , then the combination of the irritants exceeds the combined exposure limit (Sharkey, 1997). Only considering acrolein (Table 4) and formaldehyde (Table 3), we report a TWA combined irritant exposure $E_{\mathrm{m}}$ of 0.31 which is not in exceedance of OSHA limits but only lower by a factor of $\sim 3$, showing that combined TWA exposures are a greater concern than TWA exposures assessed individually. However, we note that the exposure mixture equation is a simplification of complex phenomena and it is unlikely that the effects of toxins add linearly (Yokelson et al., 2013; Menser and Heggestad, 1966; Mauderly and Samet, 2009). $E_{\mathrm{m}}$ is used as an estimate of combined exposure effects as the actual synergistic effects of a given pollutant combination are unknown. Additionally, we ignore the effects of particles which likely affect exposure limits for individual and combined species (Pope and Dockery, 2006; Adetona et al., 2011). This work agrees with previous works that "shift-average" TWA exposures may be less of a problem than peak exposures (Sharkey, 1997; Reinhardt and Ottmar, 2004; Austin, 2008), however, combined TWA exposures must be considered for a more realistic assessment of fire-line risk.

\section{Conclusions}

We measured trace gas emission factors for three prescribed fires at Fort Jackson, SC using an open-path Fourier transform infrared (OP-FTIR) system. The fires occurred outside the common range of conditions for southeastern US prescribed fires because the fuels included stands that had not been burned by prescribed fire in decades and the stands had recently been subject to drought. Thus, the emissions may be somewhat relevant to a scenario where frequency of prescribed fire is reduced, or to a wildfire.

The OP-FTIR measured a fire-averaged modified combustion efficiency (MCE) closer to that of the airborne FTIR (AFTIR) system than to the land-based FTIR (LAFTIR). This suggests that local ignition before plume development and to a lesser extent, downdrafts after plume development, may contribute significantly to the ground level smoke layer. Burn managers maximize smoke lofting so airborne measurements provide the best fire integrated sample in the absence of abundant residual smoldering combustion (RSC). However, the LAFTIR enables modeling of specific RSC fuels, but the OP-FTIR may be a less biased sample of the ground-level smoke layer. More coordinated and extensive ground-based sampling of emissions and fuel consumption would be of value in future experiments.

We observed a decrease in MCE between the "early" and "late" periods of the OP-FTIR measurements indicative of a shift from flaming-dominated combustion (immediately after adjacent ignition) to smoldering dominated combustion. We compared OP-FTIR fire-average and "early" and "late" emission factors with EF measured on the same fires by LAFTIR and AFTIR (Akagi et al., 2013). For the majority of gases there was large scatter in the fire-to-fire and species-tospecies comparisons, suggesting that the various platforms preferentially sampled the emissions from different fuels. This is likely due to the high natural variability of the fire 
Table 4. Estimated OP-FTIR TWA burn-averaged and peak concentrations, LAFTIR peak concentrations, and recommended TWA and peak exposures.

\begin{tabular}{|c|c|c|c|c|c|c|}
\hline & 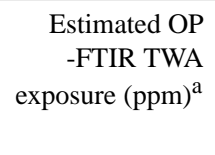 & $\begin{array}{r}\text { Recommended } \\
\text { TWA exposure } \\
(\mathrm{ppm})^{\mathrm{b}}\end{array}$ & $\begin{array}{r}E_{\mathrm{X}} \text { (estimated } \\
\text { exposure/ } \\
\text { Recommended } \\
\text { exposure) }^{\mathrm{c}}\end{array}$ & $\begin{array}{r}\text { Estimated OP- } \\
\text { FTIR peak } \\
\text { exposure } \\
(\mathrm{ppm})^{\mathrm{a}}\end{array}$ & $\begin{array}{r}\text { Estimated } \\
\text { LAFTIR peak } \\
\text { exposure } \\
(\mathrm{ppm})^{\mathrm{a}}\end{array}$ & $\begin{array}{r}\text { Recommended } \\
\text { STEL peak } \\
\text { exposure } \\
(\mathrm{ppm})^{\mathrm{d}}\end{array}$ \\
\hline Acrolein $\left(\mathrm{C}_{3} \mathrm{H}_{4} \mathrm{O}\right)$ & 0.0109 & 0.1 & $1.09 \times 10^{-1}$ & 0.055 & $1.102^{\mathrm{e}}$ & 0.3 \\
\hline Ammonia $\left(\mathrm{NH}_{3}\right)^{\mathrm{f}}$ & 0.206 & $25-50$ & $4.12 \times 10^{-3}$ & 0.493 & 1.106 & 35 \\
\hline Benzene $\left(\mathrm{C}_{6} \mathrm{H}_{6}\right)$ & 0.0058 & $0.1-1.0$ & $5.81 \times 10^{-3}$ & 0.029 & 0.587 & $1.0-5.0$ \\
\hline Hydrogen Cyanide (HCN) & 0.0540 & 10 & $5.40 \times 10^{-3}$ & 0.273 & $5.456^{\mathrm{e}}$ & 4.5 \\
\hline Hydrochloric Acid $(\mathrm{HCl})$ & 0.0043 & $2.0-5.0$ & $8.68 \times 10^{-4}$ & 0.022 & 0.438 & $3.0-7.0$ \\
\hline Acetonitrile $\left(\mathrm{CH}_{3} \mathrm{CN}\right)$ & 0.0079 & $20-40$ & $1.98 \times 10^{-4}$ & 0.040 & 0.801 & 60 \\
\hline Acetaldehyde $\left(\mathrm{CH}_{3} \mathrm{CHO}\right)$ & 0.0385 & 100 & $3.85 \times 10^{-4}$ & 0.195 & 3.885 & 150 \\
\hline Formaldehyde $(\mathrm{HCHO})^{\mathrm{f}}$ & 0.147 & $0.016-0.75$ & $1.96 \times 10^{-1}$ & 0.825 & 7.665 & $0.1-2.0$ \\
\hline Methanol $\left(\mathrm{CH}_{3} \mathrm{OH}\right)^{\mathrm{f}}$ & 0.1200 & 200 & $6.00 \times 10^{-4}$ & 0.560 & 15.65 & 250 \\
\hline Acrylonitrile $\left(\mathrm{C}_{3} \mathrm{H}_{3} \mathrm{~N}\right)$ & 0.0010 & $1.0-2.0$ & $5.07 \times 10^{-4}$ & 0.005 & 0.102 & 10 \\
\hline 1,3-Butadiene $\left(\mathrm{C}_{4} \mathrm{H}_{6}\right)$ & 0.0001 & $1.0-2.0$ & $7.48 \times 10^{-5}$ & 0.0004 & 0.008 & 5 \\
\hline Propanal $\left(\mathrm{C}_{3} \mathrm{H}_{6} \mathrm{O}\right)$ & 0.0043 & 20 & $2.14 \times 10^{-4}$ & 0.022 & 0.433 & - \\
\hline Acetone $\left(\mathrm{C}_{3} \mathrm{H}_{6} \mathrm{O}\right)$ & 0.0150 & $250-1000$ & $1.50 \times 10^{-5}$ & 0.076 & 1.514 & 1000 \\
\hline 1,1-Dimethylhydrazine $\left(\mathrm{C}_{2} \mathrm{H}_{8} \mathrm{~N}_{2}\right)$ & 0.0014 & 0.5 & $2.70 \times 10^{-3}$ & 0.007 & 0.136 & - \\
\hline Crotonaldehyde $\left(\mathrm{C}_{4} \mathrm{H}_{6} \mathrm{O}\right)$ & 0.0074 & 2.0 & $3.68 \times 10^{-3}$ & 0.037 & 0.743 & - \\
\hline Acrylic Acid $\left(\mathrm{C}_{3} \mathrm{H}_{4} \mathrm{O}_{2}\right)$ & 0.0013 & $2.0-10.0$ & $1.33 \times 10^{-4}$ & 0.007 & 0.134 & - \\
\hline Methyl Ethyl Ketone (MEK, $\mathrm{C}_{4} \mathrm{H}_{8} \mathrm{O}$ ) & 0.0041 & 200 & $2.07 \times 10^{-5}$ & 0.021 & 0.418 & 300 \\
\hline n-Hexane $\left(\mathrm{C}_{6} \mathrm{H}_{14}\right)$ & 0.0006 & $50-500$ & $1.21 \times 10^{-6}$ & 0.003 & 0.061 & 510 \\
\hline Toluene $\left(\mathrm{C}_{6} \mathrm{H}_{5} \mathrm{CH}_{3}\right)$ & 0.0038 & $50-200$ & $1.89 \times 10^{-5}$ & 0.019 & 0.381 & 500 \\
\hline Phenol $\left(\mathrm{C}_{6} \mathrm{H}_{5} \mathrm{OH}\right)$ & 0.0088 & 5 & $1.76 \times 10^{-3}$ & 0.044 & 0.887 & 15.6 \\
\hline Methyl Methacrylate $\left(\mathrm{C}_{5} \mathrm{H}_{8} \mathrm{O}_{2}\right)$ & 0.0009 & $50-100$ & $9.21 \times 10^{-6}$ & 0.005 & 0.093 & 100 \\
\hline Styrene $\left(\mathrm{C}_{8} \mathrm{H}_{8}\right)$ & 0.0012 & $20-100$ & $1.16 \times 10^{-5}$ & 0.006 & 0.117 & $40-200$ \\
\hline Xylenes $\left(\mathrm{C}_{8} \mathrm{H}_{10}\right)$ & 0.0031 & 100 & $3.07 \times 10^{-5}$ & 0.016 & 0.310 & $150-200$ \\
\hline Ethylbenzene $\left(\mathrm{C}_{8} \mathrm{H}_{10}\right)$ & 0.0009 & 100 & $8.95 \times 10^{-6}$ & 0.005 & 0.090 & 125 \\
\hline Naphthalene $\left(\mathrm{C}_{10} \mathrm{H}_{8}\right)$ & 0.0038 & 10 & $3.83 \times 10^{-4}$ & 0.019 & 0.387 & 15 \\
\hline Isocyanic Acid (HNCO) ${ }^{\mathrm{g}}$ & 0.0052 & - & - & 0.026 & 0.524 & - \\
\hline
\end{tabular}

environment coupled with the spatial separation between the systems. The largest differences between ground-based systems were seen for $\mathrm{CH}_{4}$ (factor of five) and the largest differences between AFTIR and OP-FTIR were for $\mathrm{NH}_{3}$, which was higher by ground-based OP-FTIR than from an aircraft. The chemistry and amount of un-lofted emissions is not highly constrained suggesting that some fires may produce higher overall $\mathrm{NH}_{3}$ emissions than would be implied by airborne measurements (Griffith, 1991; Wooster et al., 2011). We also observed very similar EF between this work and EF measured on prescribed African savanna fires by a similar OP-FTIR system, despite the fact that the fires burned in very different ecosystems, fuel types, weather conditions, etc. This also suggests that MCE and trace gas EFs can be highly dependent on the measurement platform.

Average and peak OP-FTIR mixing ratios and peak LAFTIR mixing ratios were compared to recommended time-weighted average (TWA) and peak exposure guidelines. We also estimated TWA and peak exposures for many air toxins not measured in this work by ratioing normalized excess mixing ratios from a comprehensive study to our real fireline CO data. This is an important approach to estimating exposures since it would be difficult to deploy large amounts of advanced instrumentation on a fire-line. Our data support previous findings that peak exposures are more likely to challenge permissible exposure limits than average exposures, suggesting it is important for wildland fire personnel to avoid concentrated smoldering smoke to minimize their risk of overexposure.

\section{Supplementary material related to this article is available online at http://www.atmos-chem-phys.net/14/ 199/2014/acp-14-199-2014-supplement.zip.}




\section{Appendix A}

Table A1. Spectral regions used to retrieve excess mixing ratios reported in this work.

\begin{tabular}{lrrr}
\hline $\begin{array}{l}\text { Target } \\
\text { species }\end{array}$ & $\begin{array}{r}\text { Spectral region } \\
\left(\mathrm{cm}^{-1}\right)\end{array}$ & $\begin{array}{r}\text { Other species } \\
\text { fitted }\end{array}$ & $\begin{array}{r}\text { Single Beam (SB) or } \\
\text { Transmission (T) }\end{array}$ \\
\hline $\mathrm{CO}, \mathrm{CO}_{2}$ & $2050-2330$ & $\mathrm{H}_{2} \mathrm{O}$ & $\mathrm{SB}$ \\
$\mathrm{CH}_{4}$ & $2990-3105$ & $\mathrm{H}_{2} \mathrm{O}$ & $\mathrm{SB}$ \\
$\mathrm{C}_{2} \mathrm{H}_{4}, \mathrm{NH}_{3}$ & $922-975$ & $\mathrm{H}_{2} \mathrm{O}$ & $\mathrm{TR}$ \\
$\mathrm{CH}_{3} \mathrm{OH}$ & $1020-1055$ & $\mathrm{NH}_{3}, \mathrm{H}_{2} \mathrm{O}$ & $\mathrm{TR}$ \\
$\mathrm{CH}_{3} \mathrm{COOH}, \mathrm{HCOOH}$ & $1100-1230$ & $\mathrm{H}_{2} \mathrm{O}, \mathrm{CH}_{4}, \mathrm{NH}_{3}$ & $\mathrm{TR}$ \\
$\mathrm{HCN}$ & $709-717$ & $\mathrm{H}_{2} \mathrm{O}$ & $\mathrm{TR}$ \\
$\mathrm{C}_{2} \mathrm{H}_{2}$, Furan & $725-755$ & $\mathrm{H}_{2} \mathrm{O}, \mathrm{CO}_{2}, 2-\mathrm{Methylfuran}_{2}$ & $\mathrm{CH}$ \\
$\mathrm{HCHO}$, Glyoxal & $2740-2850$ & $\mathrm{CH}_{4}, \mathrm{H}_{2} \mathrm{O}$ & $\mathrm{TR}$ \\
\hline
\end{tabular}

Table A2. Estimated and measured exposures for species measured both by the OP-FTIR and in Yokelson et al. (2013) reported as excess mixing ratios (see Sect. 3.5 for discussion).

\begin{tabular}{|c|c|c|c|c|}
\hline & & $\begin{array}{l}\text { OP-FTIR TWA } \\
\text { exposure (ppm) }\end{array}$ & $\begin{array}{r}\text { OP-FTIR peak } \\
\text { exposure (ppm) }\end{array}$ & $\begin{array}{r}\text { LAFTIR peak } \\
\text { exposure (ppm) }\end{array}$ \\
\hline \multirow[t]{3}{*}{ Formaldehyde (HCHO) } & Estimated $^{\mathrm{a}}$ & 0.12 & 0.63 & 12.52 \\
\hline & Measured $^{\mathrm{b}}$ & $0.147^{\mathrm{c}}$ & 0.825 & 7.665 \\
\hline & Estimated/Measured & 0.82 & 0.76 & 1.63 \\
\hline \multirow[t]{3}{*}{ Methanol $\left(\mathrm{CH}_{3} \mathrm{OH}\right)$} & Estimated $^{\mathrm{a}}$ & 0.081 & 0.409 & 8.165 \\
\hline & Measured & 0.120 & 0.56 & 15.65 \\
\hline & Estimated/Measured & 0.67 & 0.73 & 0.52 \\
\hline \multirow[t]{3}{*}{ Ammonia $\left(\mathrm{NH}_{3}\right)$} & Estimated $^{\mathrm{a}}$ & 0.072 & 0.366 & 7.304 \\
\hline & Measured & 0.206 & 0.493 & 1.106 \\
\hline & Estimated/Measured & 0.35 & 0.74 & 6.60 \\
\hline
\end{tabular}

${ }^{a}$ Estimated from pine-understory fire $\operatorname{ER}(\Delta \mathrm{X} / \Delta \mathrm{CO})$ (from Yokelson et al., 2013) multiplied by the burn-average $\Delta \mathrm{CO}$ measured by the OP-FTIR (Table 3). ${ }^{b}$ Shown in Table $3 .{ }^{c}$ Since we do not report HCHO measured from the start to end of the Fort Jackson fires, this value was estimated as $\mathrm{ER}(\Delta \mathrm{HCHO} / \triangle \mathrm{CO}) \times \mathrm{OP}$-FTIR (burn-average) $\Delta \mathrm{CO}$.

Acknowledgements. This work was supported by the Strategic Environmental Research and Development Program (SERDP) project RC-1649 and administered partly through Forest Service Research Joint Venture Agreement 08JV11272166039, and we thank the sponsors for their support. We greatly appreciate the collaboration and efforts of John Maitland and forestry staff at Fort Jackson.

Edited by: P. O. Wennberg

\section{References}

Aan de Brugh, J. M. J., Henzing, J. S., Schaap, M., Morgan, W. T., van Heerwaarden, C. C., Weijers, E. P., Coe, H., and Krol, M. C.: Modelling the partitioning of ammonium nitrate in the convective boundary layer, Atmos. Chem. Phys., 12, 3005-3023, doi:10.5194/acp-12-3005-2012, 2012.

Achtemeier, G. L.: Measurements of moisture in smoldering smoke and implications for fog, Int. J. Wildland Fire, 15, 517-525, doi:10.1071/WF05115, 2006.
Adetona, O., Dunn, K., Hall, D. B., Achtemeier, G., Stock, A., and Naeher, L. P.: Personal $\mathrm{PM}_{2.5}$ exposure among wildland firefighters working at prescribed forest burns in southeastern United States, J. Occup. Environ. Hyg., 8, 503-511, 2011.

Akagi, S. K., Yokelson, R. J., Wiedinmyer, C., Alvarado, M. J., Reid, J. S., Karl, T., Crounse, J. D., and Wennberg, P. O.: Emission factors for open and domestic biomass burning for use in atmospheric models, Atmos. Chem. Phys., 11, 4039-4072, doi:10.5194/acp-11-4039-2011, 2011.

Akagi, S. K., Craven, J. S., Taylor, J. W., McMeeking, G. R., Yokelson, R. J., Burling, I. R., Urbanski, S. P., Wold, C. E., Seinfeld, J. H., Coe, H., Alvarado, M. J., and Weise, D. R.: Evolution of trace gases and particles emitted by a chaparral fire in California, Atmos. Chem. Phys., 12, 1397-1421, doi:10.5194/acp-12-13972012, 2012.

Akagi, S. K., Yokelson, R. J., Burling, I. R., Meinardi, S., Simpson, I., Blake, D. R., McMeeking, G. R., Sullivan, A., Lee, T., Kreidenweis, S., Urbanski, S., Reardon, J., Griffith, D. W. T., Johnson, T. J., and Weise, D. R.: Measurements of reactive trace gases and variable $\mathrm{O}_{3}$ formation rates in some South Carolina biomass burning plumes, Atmos. Chem. Phys., 13, 1141-1165, doi:10.5194/acp-13-1141-2013, 2013. 
Austin, C.: Wildland firefighter health risks and respiratory protection. Institut de recherche Robert Sauvé en santé et en sécurité du travail (IRSST), Report R-572, 2008.

Benscoter, B. W., Thompson, D. K., Waddington, J. M., Flannigan, M. D., Wotton, B. M., de Groot, W. J., and Turetsky, M. R.: Interactive effects of vegetation, soil moisture and bulk density on depth of burning of thick organic soils, Int. J. Wildland Fire, 20, 418-429, 2011.

Bertschi, I. T., Yokelson, R. J., Ward, D. E., Babbitt, R. E., Susott, R. A., Goode, J. G., and Hao, W. M.: Trace gas and particle emissions from fires in large diameter and belowground biomass fuels, J. Geophys. Res., 108, 8472, doi:10.1029/2002JD002100, 2003.

Biswell, H. H.: Prescribed burning in California wildlands vegetation management, Berkeley, CA: University of California Press; p. 255, 1989.

Burling, I. R., Yokelson, R. J., Griffith, D. W. T., Johnson, T. J., Veres, P., Roberts, J. M., Warneke, C., Urbanski, S. P., Reardon, J., Weise, D. R., Hao, W. M., and de Gouw, J.: Laboratory measurements of trace gas emissions from biomass burning of fuel types from the southeastern and southwestern United States, Atmos. Chem. Phys., 10, 11115-11130, doi:10.5194/acp10-11115-2010, 2010.

Burling, I. R., Yokelson, R. J., Akagi, S. K., Urbanski, S. P., Wold, C. E., Griffith, D. W. T., Johnson, T. J., Reardon, J., and Weise, D. R.: Airborne and ground-based measurements of the trace gases and particles emitted by prescribed fires in the United States, Atmos. Chem. Phys., 11, 12197-12216, doi:10.5194/acp11-12197-2011, 2011.

Carter, M. C. and Foster, C. D.: Prescribed burning and productivity in southern pine forests: a review, Forest Ecol. Manag., 191, 93109,2004

Christian, T. J., Yokelson, R. J., Carvalho Jr., J. A., Griffith, D. W. T., Alvarado, E. C., Santos, J. C., Neto, T. G. S., Veras, C. A. G., and Hao, W. M.: The tropical forest and fire emissions experiment: Trace gases emitted by smoldering logs and dung from deforestation and pasture fires in Brazil, J. Geophys. Res., 112, D18308, doi:10.1029/2006JD008147, 2007.

Cochrane, M. A., Moran, C. J., Wimberly, M. C., Baer, A. D., Finney, M. A., Beckendorf, K. L., Eidenshink, J., and Zhu, Z.: Estimation of wildfire size and risk changes due to fuels treatments, Int. J. Wildland Fire, 21, 357-367, 2012.

Crutzen, P. J. and Andreae, M. O.: Biomass burning in the tropics: Impact on atmospheric chemistry and biogeochemical cycles, Science, 250, 1669-1678, 1990.

Demers, P. A., Checkoway, H., Vaughan, T. L., Weiss, N. S., Heyer, N. J., and Rosenstock, L.: Cancer incidence among firefighters in Seattle and Tacoma, Washington (United States), Cancer Cause. Control, 5, 129-135, 1994.

Gosz, J. R., Dahm, C. N., and Risser, P. G.: Long-path FTIR measurement of atmospheric trace gas concentrations, Ecology, 69, 1326-1330, 1988.

Greene, D. F., Macdonald, S. E., Hauessler, S., Domenicano, S., Noel, J., Jayen, K., Charron, I., Guathier, S., Hunt, S., Gielau, E. T., Bergeron, Y., and Swift, L.: The reduction of organic-layer depth by wildfire in the North American boreal forest and its effect on tree recruitment by seed, Can. J. Forest Res., 37, 10121023, 2007.
Griffith, D. W. T., Mankin, W. G., Coffey, M. T., Ward, D. E., and Riebau, A.: FTIR remote sensing of biomass burning emissions of $\mathrm{CO}_{2}, \mathrm{CO}, \mathrm{CH}_{4}, \mathrm{CH}_{2} \mathrm{O}, \mathrm{NO}, \mathrm{NO}_{2}, \mathrm{NH}_{3}$, and $\mathrm{N}_{2} \mathrm{O}$, in Global Biomass Burning: Atmospheric, Climatic, and Biospheric Implications, MIT Press, edited by: Levine, J., 230-240, 1991.

Griffith, D. W. T., Deutscher, N. M., Caldow, C., Kettlewell, G., Riggenbach, M., and Hammer, S.: A Fourier transform infrared trace gas and isotope analyser for atmospheric applications, Atmos. Meas. Tech., 5, 2481-2498, doi:10.5194/amt-5-2481-2012, 2012.

Hardy, C. C., Ottmar, R. D., Peterson, J. L., Core, J. E., and Seamon, P.: Smoke management guide for prescribed and wildland fire; 2001 ed., PMS 420-2, National Wildfire Coordinating group, Boise, ID. 226 pp., 2001.

Hyde, J. C., Smith, A. M. S., Ottmar, R. D., Alvarado, E. C., and Morgan, P.: The combustion of sound and rotten coarse woody debris: a review, Int. J. Wildland Fire, 20, 163-174, 2011.

Johnson, T. J., Masiello, T., and Sharpe, S. W.: The quantitative infrared and NIR spectrum of $\mathrm{CH}_{2} \mathrm{I}_{2}$ vapor: vibrational assignments and potential for atmospheric monitoring, Atmos. Chem. Phys., 6, 2581-2591, doi:10.5194/acp-6-2581-2006, 2006.

Johnson, T. J., Profeta, L. T. M., Sams, R. L., Griffith, D. W. T., and Yokelson, R. J.: An infrared spectral database for detection of gases emitted by biomass burning, Vib. Spectrosc., 53, 97-102, doi:10.1016/j.vibspec.2010.02.010, 2010.

Keeley, J. E., Aplet, G. H., Christensen, N. L., Conard, S. G., Johnson, E. A., Omi, P. N., Peterson, D. L., and Swetnam, T. W.: Ecological foundations for fire management in North American Forest and shrubland ecosystems, General Technical Report PNWGTR-779, Portland: US Forest Service, 2009.

Keene, W. C., Lobert, J. M., Crutzen, P. J., Maben, J. R., Scharffe, D. H., Landmann, T., Hely, C., and Brain, C.: Emissions of major gaseous and particulate species during experimental burns of southern African biomass, J. Geophys. Res., 111, D04301, doi:10.1029/2005jd006319, 2006.

Keens, A. and Simon, A.: Correction of non-linearities in detectors in Fourier transform spectroscopy, United States Patent 4927269, 1990.

Lobert, J. M., Scharffe, D. H., Hao, W. M., Kuhlbusch, T. A., Seuwen, R., Warneck, P., and Crutzen, P. J.: Experimental evaluation of biomass burning emissions: nitrogen and carbon containing compounds, in: Global Biomass Burning: Atmospheric, Climatic, and Biospheric Implications, edited by: Levine, J. S., MIT Press, Cambridge, 289-304, 1991.

Materna, B. L., Jones, J. R., Sutton, P. M., Rothman, N., and Harrison, R. J.: Occupational exposures in California wildland fire fighting, Am. Ind. Hyg. Assoc. J., 53, 69-76, 1992.

Melvin, M. A.: 2012 National prescribed fire use survey report, Technical Report 01-12, Coalition of Prescribed Fire Councils, Inc., 1-19, 2012.

Menser, H. A. and Heggestad, H. E.: Ozone and sulfur dioxide synergism: Injury to tobacco plants, Science, 153, 424-425, doi:10.1126/science.153.3734.424, 1966.

Mauderly, J. L. and Samet, J. M.: Is there evidence for synergy among air pollutants in causing health effects?, Environ. Health Persp., 117, 1-6, 2009.

Naeher, L. P., Brauer, M., Lipsett, M., Zelikoff, J. T., Simpson, C. D., Koenig, J. Q., and Smith, K. R.: Woodsmoke 
health effects: A review, Inhal. Toxicol., 19, 67-106, doi:10.1080/08958370600985875, 2007.

Norman, M., Spirig, C., Wolff, V., Trebs, I., Flechard, C., Wisthaler, A., Schnitzhofer, R., Hansel, A., and Neftel, A.: Intercomparison of ammonia measurement techniques at an intensively managed grassland site (Oensingen, Switzerland), Atmos. Chem. Phys., 9, 2635-2645, doi:10.5194/acp-9-2635-2009, 2009.

Oppenheimer, C. and Kyle, P. R.: Probing the magma plumbing of Erebus volcano, Antarctica, by open-path FTIR spectroscopy of gas emissions, J. Volcanol. Geoth. Res., 1, 743-754, 2007.

Pope III, C. A. and Dockery, D. W.: Health effects of fine particulate air pollution: lines that connect, J. Air Waste Manage., 56, 709742, 2006

Profeta, L. T. M., Sams, R. L., and Johnson, T. J.: Quantitative infrared intensity studies of vapor-phase glyoxal, methylglyoxal, and 2, 3-butanedione (diacetyl) with vibrational assignments, J. Phys. Chem. A, 115, 9886-9900, 2011.

Reinhardt, T. E. and Ottmar, R. D.: Smoke Exposure Among Wildland Firefighters: A Review and Discussion of Current Literature, Report PNW-GTR-373, Portland, OR.: US Department of Agriculture, Forest Service, Pacific Northwest Research Station, 1997.

Reinhardt, T. E. and Ottmar, R. D.: Baseline measurements of smoke exposure among wildland firefighters, J. Occup. Environ. Hyg., 1, 593-606, doi:10.1080/15459620490490101, 2004.

Roberts, J. M., Veres, P. R., Cochran, A. K., Warneke, C., Burling, I. R., Yokelson, R. J., Lerner, B., Holloway, J. S., Fall, R., and de Gouw, J.: Isocyanic acid in the atmosphere: Sources, concentrations and sinks, and potential health effects, Proc. Natl. Acad. Sci. USA, 108, 8966-8971, doi:10.1073/pnas.1103352108, 2011.

Rothman, L. S., Gordon, I. E., Barbe, A., Benner, D. C., Bernath, P. F., Birk, M., Boudon, V., Brown, L. R., Campargue, A., Champion, J. P., Chance, K., Coudert, L. H., Dana, V., Devi, V. M., Fally, S., Flaud, J. M., Gamache, R. R., Goldman, A., Jacquemart, D., Kleiner, I., Lacome, N., Lafferty, W. J., Mandin, J. Y., Massie, S. T., Mikhailenko, S. N., Miller, C. E., Moazzen-Ahmadi, N., Naumenko, O. V., Nikitin, A. V., Orphal, J., Perevalov, V. I., Perrin, A., Predoi-Cross, A., Rinsland, C. P., Rotger, M., Simecková, M., Smith, M. A. H., Sung, K., Tashkun, S. A., Tennyson, J., Toth, R. A., Vandaele, A. C., and Vander Auwera, J.: The HITRAN 2008 molecular spectroscopic database, J. Quant. Spectrosc. Ra., 110, 533-572, 2009.

Schäfer, K., Jahn, C., Utzig, S., Flores-Jardines, E., Harig, R., and Rusch, P.: Remote measurement of the plume shape of aircraft exhausts at airports by passive FTIR spectrometry, in: Remote Sensing of Clouds and the Atmosphere IX, edited by: Schäfer, K., Comeron, A., Carleer, M., Picard, R. H., and Sifakis, N., Proc. SPIE, Bellingham, WA, US, 5571, 334-344, 2005.

Sharkey, B. (Ed.): Health Hazards of Smoke: Recommendations of the April 1997 Consensus Conference, Tech. Rep. 9751-2836MTDC, 84 pp., Missoula Technol. and Dev. Cent., USDA For. Serv., Missoula, Montana, US, 1997.

Sharpe, S. W., Johnson, T. J., Sams, R. L., Chu, P. M., Rhoderick, G. C., and Johnson, P. A.: Gas phase databases for quantitative infrared spectroscopy, Appl. Spectrosc., 58, 1452-1461, 2004.

Smith, T. E. L., Wooster, M. J., Tattaris, M., and Griffith, D. W. T.: Absolute accuracy and sensitivity analysis of OP-FTIR retrievals of $\mathrm{CO}_{2}, \mathrm{CH}_{4}$ and $\mathrm{CO}$ over concentrations representative of "clean air" and "polluted plumes", Atmos. Meas. Tech., 4, 97 116, doi:10.5194/amt-4-97-2011, 2011.

Susott, R. A., Olbu, G. J., Baker, S. P., Ward, D. E. Kauffman, J. B., and Shea, R. W.: Carbon, hydrogen, nitrogen, and thermogravimetric analysis of tropical ecosystem biomass, in: Global Biomass Burning: Atmospheric, Climatic, and Biospheric Implications, edited by: Levine, J. S., 249-259, MIT Press, Cambridge, MA, 1996.

Swiston, J. R., Davidson, W., Attridge, S., Li, G. T., Brauer, M., and van Eeden, S. F.: Wood smoke exposure induces a pulmonary and systemic inflammatory response in firefighters, Eur. Respir. J., 32, 129-138, doi:10.1183/09031936.00097707, 2008.

Turetsky, M. R., Kane, E. S., Harden, J. W., Ottmar, R. D., Manies, K. L., Hoy E., and Kasischke, E. S.: Recent acceleration of biomass burning and carbon losses in Alaskan forests and peatlands, Nat. Geosci., 4, 27-31, doi:10.1038/ngeo1027, 2011.

Ward, D. E. and Radke, L. F.: Emissions measurements from vegetation fires: A Comparative evaluation of methods and results, Fire in the Environment, in: The Ecological, Atmospheric and Climatic Importance of Vegetation Fires, edited by: Crutzen, P. J. and Goldammer, J. G., John Wiley, New York, 53-76, 1993.

Wiedinmyer, C. and Hurteau, M. D.: Prescribed fire as a means of reducing forest carbon emissions in the Western United States, Environ. Sci. Technol., 44, 1926-1932, 2010.

Wooster, M. J., Freeborn, P. H., Archibald, S., Oppenheimer, C., Roberts, G. J., Smith, T. E. L., Govender, N., Burton, M., and Palumbo, I.: Field determination of biomass burning emission ratios and factors via open-path FTIR spectroscopy and fire radiative power assessment: headfire, backfire and residual smouldering combustion in African savannahs, Atmos. Chem. Phys., 11, 11591-11615, doi:10.5194/acp-11-11591-2011, 2011.

Yokelson, R. J., Griffith, D. W. T., and Ward, D. E.: Open path Fourier transform infrared studies of large-scale laboratory biomass fires, J. Geophys. Res., 101, 21067-21080, doi:10.1029/96JD01800, 1996.

Yokelson, R. J., Goode, J. G., Ward, D. E., Susott, R. A., Babbitt, R. E., Wade, D. D., Bertschi, I., Griffith, D. W. T., and Hao, W. M.: Emissions of formaldehyde, acetic acid, methanol, and other trace gases from biomass fires in North Carolina measured by airborne Fourier transform infrared spectroscopy, J. Geophys. Res., 104, 30109-30126, doi:10.1029/1999JD900817, 1999.

Yokelson, R. J., Christian, T. J., Bertschi, I. T., and Hao, W. M.: Evaluation of adsorption effects on measurements of ammonia, acetic acid, and methanol, J. Geophys. Res., 108, 4649, doi:10.1029/2003JD003549, 2003.

Yokelson, R. J., Burling, I. R., Urbanski, S. P., Atlas, E. L., Adachi, K., Buseck, P. R., Wiedinmyer, C., Akagi, S. K., Toohey, D. W., and Wold, C. E.: Trace gas and particle emissions from open biomass burning in Mexico, Atmos. Chem. Phys., 11, 67876808, doi:10.5194/acp-11-6787-2011, 2011.

Yokelson, R. J., Burling, I. R., Gilman, J. B., Warneke, C., Stockwell, C. E., de Gouw, J., Akagi, S. K., Urbanski, S. P., Veres, P., Roberts, J. M., Kuster, W. C., Reardon, J., Griffith, D. W. T., Johnson, T. J., Hosseini, S., Miller, J. W., Cocker III, D. R., Jung, H., and Weise, D. R.: Coupling field and laboratory measurements to estimate the emission factors of identified and unidentified trace gases for prescribed fires, Atmos. Chem. Phys., 13, 89-116, doi:10.5194/acp-13-89-2013, 2013. 